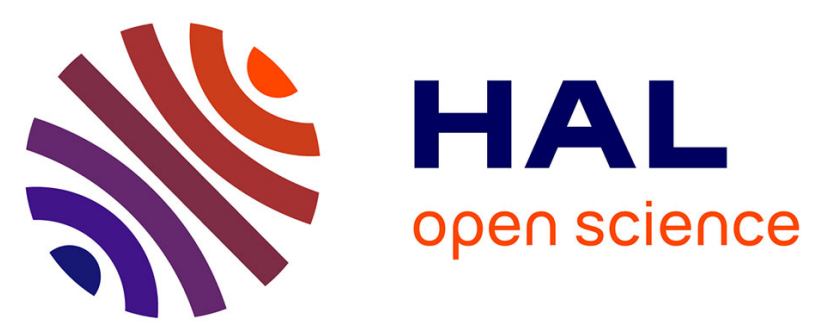

\title{
From agricultural catchment to management scenarios: A modular tool to assess effects of landscape features on water and pesticide behavior
}

Emilie Rouzies, Claire Lauvernet, C. Barachet, Thierry Morel, F. Branger, Isabelle Braud, Nadia Carluer

\section{To cite this version:}

Emilie Rouzies, Claire Lauvernet, C. Barachet, Thierry Morel, F. Branger, et al.. From agricultural catchment to management scenarios: A modular tool to assess effects of landscape features on water and pesticide behavior. Science of the Total Environment, 2019, 671, pp.1144-1160. 10.1016/j.scitotenv.2019.03.060 . hal-02609270

\section{HAL Id: hal-02609270 \\ https://hal.inrae.fr/hal-02609270}

Submitted on 16 May 2020

HAL is a multi-disciplinary open access archive for the deposit and dissemination of scientific research documents, whether they are published or not. The documents may come from teaching and research institutions in France or abroad, or from public or private research centers.
L'archive ouverte pluridisciplinaire HAL, est destinée au dépôt et à la diffusion de documents scientifiques de niveau recherche, publiés ou non, émanant des établissements d'enseignement et de recherche français ou étrangers, des laboratoires publics ou privés. 


\title{
From agricultural catchment to management scenarios : a modular tool to assess effects of landscape features on water and pesticide behavior
}

\author{
Emilie Rouzies $^{\mathrm{a}, *}$, Claire Lauvernet ${ }^{\mathrm{a}}$, Christine Barachet $^{\mathrm{a}}$, ${\text { Thierry } \text { Morel }^{\mathrm{b}} \text {, Flora Branger }}^{\mathrm{a}}$, Isabelle Braud ${ }^{\mathrm{a}}, \mathrm{Nadia}^{\mathrm{a}}$ \\ Carluer $^{\mathrm{a}}$ \\ ${ }^{a}$ Irstea, UR RIVERLY, 5 rue de la Doua, CS 20244, 69625 Villeurbanne Cedex, France \\ ${ }^{b}$ CERFACS, 42 avenue Gaspard Coriolis, 31057 Toulouse Cedex 01, France
}

\begin{abstract}
Pesticide transfers and fate are highly influenced by the presence of discontinuities such as grass strips, slopes, hedgerows or roads that can accelerate or slow down and dissipate water and contaminant fluxes. That is why those landscape elements must be integrated into watershed management plans. It implies taking them into account when modeling water and contaminant fluxes at the small catchment scale. However, if the influence of landscape elements has already been widely explored at field scale, models generally do not reach the catchment scale. The project PESHMELBA aims at developing a new modeling tool of water and contaminants circulation and fate at the scale of small catchments in order to optimize landscape organization. The model explicitly takes into account spatial organization of landscape by representing existing elements, their locations and shapes. The final aim of this modeling tool is to efficiently test and rank different development scenarios in order to assess the influence of agricultural practices, land uses and landscape management strategies on water quality. In PESHMELBA, dominating processes ruling water and contaminants circulation and dissipation for each element type are mainly represented by existing and validated models. New components have also been developed when no suitable model was found in the literature. All these models present different levels of conceptualization and are used as modeling units ensuring a modular structure. Then, the different units are gathered and connected in the OpenPALM coupler (Fouilloux and Piacentini, 1999) in order to implement the spatial and temporal couplings. This innovative approach leads to a spatialized model of the whole catchment. Applications cases are tested with an increasing complexity, from a case with two plots to the hillslope scale with several plots, ditches and rivers. They show that PESHMELBA is a promising tool to compare scenarios considering water and pesticide fate in different complex landscapes.
\end{abstract}

Keywords: pesticide behavior, spatialized modeling, agricultural catchment, landscape scenarios, contamination management

\section{Introduction}

Occurrence of pesticides in surface and groundwater is a major concern regarding water quality in agricultural watersheds. At the catchment scale, pesticide transfers depend on soil characteristics, slopes and rainfall patterns, but are also influenced by agricultural and landscape management practices (Campbell et al., 2004). Indeed,

\footnotetext{
* Corresponding author

Email address: emilie.rouzies@irstea.fr (Emilie Rouzies)
} 
5 landscape elements can generate discontinuities of water and pesticide fluxes, depending on their nature and their characteristics. For example, grass buffer zones reduce surface velocity limiting runoff and enhancing infiltration, pesticide trapping and degradation (Muñoz-Carpena et al., 1999; Poletika et al., 2009) and can thus be used as Best Management Practices (BMPs) (Reichenberger et al., 2007, Gevaert et al., 2008; Alix et al., 2017; Carluer et al., 2017a). On the opposite, ditches can accelerate transfers to the outlet by collecting and transmitting runoff (Buchanan et al., 2013). However, depending on the slope, the substrate and the vegetation implantation, ditches may also have a positive effect, increasing retention capacities (Elsaesser et al., 2013; Stehle et al., 2011; Margoum et al. 2001, Dollinger et al. 2016). Similarly, roads can prevent overland flow downslope but they can also speed up transfers of water and dissolved contaminants toward stream channels (Leopold \& Dunne, 1978; Jones et al., 2000). As a result, all the elements present in the watershed, their position, their design and their specific functioning must be considered all together, as an ensemble for setting mitigation strategies to preserve water resources.

What's more, in this objective of preservation of water resources, it is not only necessary to take into account the landscape organization but also to consider specific subsurface functioning of the catchment. In that way, catchments where surface runoff and shallow subsurface flow strongly interact and where subsoil is impervious rock require special attention. They can be characterized for instance by the formation of shallowly perched water table near the surface. Those configurations are quite common in Europe (Dubus \& Surdyk, 2006) and they make the water resources particularly vulnerable as it is located close to the surface. This knowledge should also be considered when implementing preventing actions.

Computer modeling is a relevant tool for determining such prevention and mitigation plans. Indeed, it makes it possible to set and to simulate different scenarios, such as adding some new buffer zones in the watershed or changing agricultural practices. These scenarios can then be evaluated in order to choose the most suitable mitigation actions. Many modeling tools account for solute transport and transfer at different scales (from field-scale to catchmentscale), taking different processes into account with different levels of complexity.

On the one hand, pesticide fate modeling at the local scale makes it possible to explore the function of specific landscape elements regarding solute fate. A large range of models were developed to simulate pesticide transport and fate at the plot scale, in particular for regulatory purposes. Among them, MACRO (Larsbo \& Jarvis, 2003) is a 1D mechanistic model dedicated to pesticide leaching and movement to drains. Its dual-permeability representation of the soil takes into account preferential flows, an important pathway for pesticide transport (Beven \& Germann, 1982; Jarvis, 2007, Beven \& Germann, 2013). Conceptual models also exist such as PRZM (Carsel \& Baldwin, 2000 ) or Pestdrain (Branger et al. 2009) that are dedicated to surface runoff and tile-drainage flow respectively with simplified approach. Additionally, some models represent water circulation and pesticide fate on other specific landscape elements such as buffer zones or ditches. VFSMOD (Muñoz-Carpena et al. 1999, 2018, Lauvernet \& Muñoz-Carpena, 2018, Sabbagh et al. 2009) simulates water, sediment and pesticides on vegetative filter strips considering rainfall event, incoming sediment and overland flows. TOXSWA Adriaanse, 1997, Beltman \& Adriaanse, 1999, Adriaanse et al., 2013) is a mechanistic model used for pesticide European certification that simulates the 40 evolution of solute concentration within the water of a ditch. It takes into account a series of biogeochemical processes that can attenuate solute transfers (Dollinger, 2016). However, the potential mitigation power of such landscape elements regarding pesticide transfer depends on their position in the catchment and their interactions 
with other elements. The models that represent solute transport and transfer at the field scale do not intrinsically take into account interactions neither with neighboring elements nor with the rest of the catchment, and those interactions can only be taken into account by setting locally adapted boundary conditions or inputs Lauvernet \& Muñoz-Carpena, 2018). Some studies include for example some VFSMOD simulations into a watershed scale tool to assess buffer performance and placement at the watershed level (Dosskey et al., 2006; Tomer et al., 2009; Carluer et al., 2017b). However, the fact remains that such methods do not allow dynamical coupling nor interactions in space and time.

In addition to local-scale models, a variety of $3 \mathrm{D}$ models are broadly used to simulate water flow pathways and pesticide transport at the catchment scale with different degrees of conceptualization. Some models, widely used for operational purposes, either fully-distributed such as annAGNPS (Bingner, 2011) or semi-distributed such as SWAT (Arnold et al. 1998) are able to take into account different land management practices. ZIN-AgriTra (Gassmann et al. 2013) is another physically-based model that simulates pesticide and transformation product fate on small agricultural catchments. In addition to simulating solutes reactive transport and transfers, ZIN-AgriTra also includes preferential flows. Original approaches also exist such as LISEM (De Roo et al., 1996), an eventbased hydrological and soil erosion model that is completely included in a raster Geographical Information System. However, such models generally represent the subsurface in a quite simplified way and cannot account for shallowly perched water tables. These can be a significant pathway for pesticide transfers, especially on catchments where surface runoff and shallow subsurface flow interact. Hence, they need to be included when modeling pesticide fate, as shown for example on vegetative filter strips that are located along the hydrographic network (Simpkins et al. 2002, Lacas et al., 2005, Muñoz-Carpena et al., 2018). Additional limits can also arise in those models if temporal resolution is not detailed enough. Temporal variability is an important feature of pesticide transfers at the catchment scale (Ippolito \& Fait, 2019) and it can be missed if the temporal resolution is too coarse. In order to accurately describe all relevant processes at the catchment scale with a high temporal resolution, Integrated Surface-Subsurface Hydrological Models (ISSHMs) can also be used. Among them, ParFlow (Ashby \& Falgout, 1996: Jones \& Woodward, 2001; Kollet \& Maxwell, 2006) or CATHY (Paniconi \& Putti, 1994, Camporese et al. 2010) give an accurate representation of water and solute surface/subsurface fluxes and interactions. Such models can also integrate a representation of reactive solute transfers (Weill et al., 2011; Beisman et al., 2015, Gatel et al. 2018). However, these 3D, surface-subsurface, physically based models are often based on a fixed mesh. It implies that they require to entirely build a new mesh when modifying one element in the modeling domain. They are thus limited for integrating different landscape elements with proper geometry, properties and processes. As a result, they can hardly constitute an exploration tool for different landscape organization scenarios.

Considering the difficulties of the existing modeling tools acting at the catchment scale to take into account the diversity of landscape elements, we may think about a different approach in order to set a model able to test different landscape management practices. As a lot of models for diverse elements and diverse processes already exist at a local scale, the following issue arises: can all of this existing knowledge be combined efficiently in order to reach the catchment scale?

One way is to rely on a modeling framework that couples models standing for different processes or elements.

That is the base for integrated modeling (Hutchings et al. 2002). Many projects are already based on this approach: 
JAMS (Kralisch \& Krause, 2006), WaterCAST (Argent et al., 2009), LIQUID (Branger et al., 2010) or ECHSE Kneis, 2015) for instance. Among them, only a few particularly address the question of pesticide fate at the hillslope scale. OpenFluid (Fabre et al. 2010) is a framework designed for modeling water and solute flows in agricultural landscapes. Nevertheless, landscape elements representation is currently limited to plots and ditches and shallow lateral subsurface flows are not accurately represented. The CMF framework (Catchment Modeling Framework) (Kraft et al. 2012) was also adapted by Djabelkhir et al. (2017) to simulate pesticide transfers at the hillslope scale. However, this toolkit is designed to simulate water fluxes or advection and does not allow an easy inclusion of reactive processes or specific landscapes features. In all, there is a real need for a flexible, modular and open-source tool that allows an easy coupling between units. This conception of modeling using coupling inside hydrological platforms is also strongly encouraged in the literature (Buytaert et al., 2008, Kraft et al., 2012, Fatichi et al. 2016) and appears to be a relevant solution to reuse existing models. However, these platforms are mainly dedicated to hydrology and hardly adaptive to reactive solutes such as pesticides (Djabelkhir, 2015). An alternative approach is the use of a code coupler such as OpenPALM (Fouilloux \& Piacentini, 1999, Buis et al. 2006) which is highly flexible and able to couple complex and high dimension models whatever the variables it is coupling (see for example, Dauptain et al., 2008; Barthélémy et al., 2018).

In this paper, we propose an innovative use of the OpenPALM code coupler to build the PESHMELBA model (Pesticides and hydrology: modeling at the catchment scale) that represents water circulation and pesticide fate at the scale of small watersheds. The final objective of PESHMELBA is to represent pesticide fate and the role of elements on their transfers in a realistic way in order to compare and to rank scenarios for decision-making. We hypothesize that the landscape organization and its composing elements are highly important when modeling water circulation and pesticide transfers and fate. That is the reason why the meshing used in PESHMELBA is designed accordingly to landscape layout. The aim of the paper is first to present the building of the model, based on (1) preexisting and validated models that stand for different processes or landscape elements and (2) additional units newly developed. All elements are thereafter coupled within the OpenPALM framework. The second part of the paper is application-oriented. Simple scenarios involving plots and ditches are proposed to analyze the first results of the coupling and to illustrate the new tool's potential considering water and solutes. In order to be consistent and to reach realistic orders of magnitude, all scenarios are based on geometry, soil properties and climate forcing taken from Kervidy, a real catchment in North-West of France (Cheverry, 1998), mostly covered with cereal plots, ditches, and some buffer zones.

\section{Material and methods}

\subsection{Preprocessing}

PESHMELBA is running on a specific meshing that relies on homogeneous surface and linear components, and not on regular elements as it is commonly done. Each surface component is characterized by a unique nature (plot, grass buffer strip, etc.), a soil type and a land use or crop itinerary and each linear reach is characterized by its nature (ditch, road, river, bank, etc.). The resulting meshing is composed of surface and linear elements which size can vary significantly as shown in the example, Figure 1 (left). Additionally to these elementary components, the 


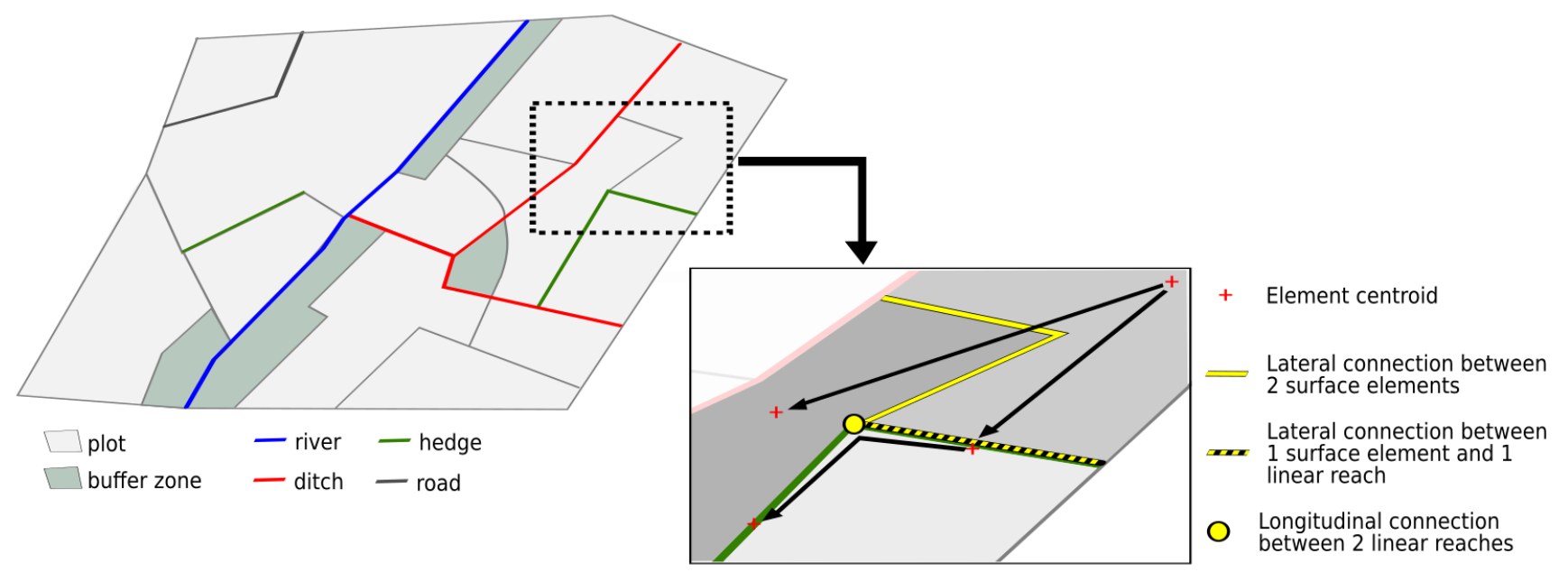

Figure 1: Surface and linear elements in a virtual catchment with example of longitudinal and lateral connections between them.

PESHMELBA meshing is also composed of the connections between elements. Connecting interfaces can be lines, typically for lateral connections between two surface elements, between two linear elements or between one surface and one linear element. Interfaces can also be points for longitudinal connections between two portions of linear (see some examples of connections Figure 1, right). Each element is one-way connected to the surrounding lower ones. However, whether it is for lateral or for longitudinal connections, each element can be connected to several elements upstream and downstream. The spatial description of all the types of elements and the connections between them in the whole catchment is the preprocessing required by PESHMELBA for any simulation.

\subsection{Modeling of processes and landscape elements}

The PESHMELBA model relies on an ensemble of elementary units that stand for one or several processes concerning water and pesticide fluxes at surface and subsurface on a landscape element. Those units are written in Fortran90 or Python, chosen among existing models or developed for the need of the project. They rely on different approaches, levels of complexity and discretization. They are presented individually in this section with some details in the appendix. All units are coupled to build the PESHMELBA model as schematized in Figure 2

This coupling within the OpenPALM framework is described in section 2.3 .

\subsubsection{Vertical infiltration and unsaturated transfers for water and solutes on plots}

Vertical infiltration and fluxes in the unsaturated zone on plots are represented by the FRER1D unit (see Appendix B.1. This unit implements the fast and simplified numerical scheme proposed by Ross (2003) and extensively tested and validated by Varado et al. (2006b) and Crevoisier et al. (2009). A plot is represented by a single column of soil divided in horizontal cells and can be composed of different soil horizons with distinct properties. FRER1D represents vertical infiltration of water in the soil, formation and evolution of saturated zones, evaporation on bare soil in response to rain and potential evapotranspiration. Surface boundary conditions are determined by the PARTITION unit that takes into account rain interception by the vegetation and plant transpiration. Inclusion of a source/sink term has also been added in order to represent lateral saturated transfers or root extraction by 


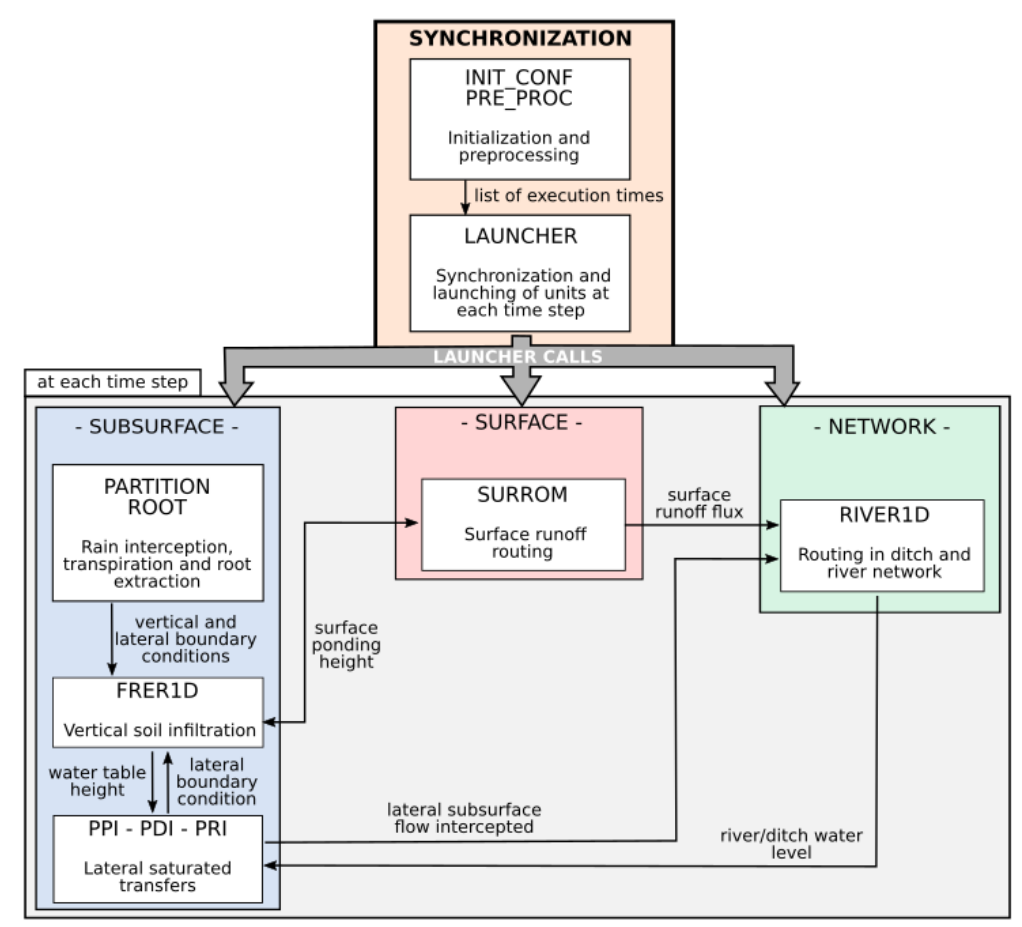

Figure 2: Schematic illustration of the PESHMELBA model structure. Colored rectangles stand for branches, white rectangles for units, arrows for the main variables exchanged between units.

coupling FRER1D with other dedicated units : unit PPI for lateral saturated transfers (see section 2.2.2 and unit ROOT for root extraction (see Appendix B.2).

Transfer and fate of several solutes can be simulated at the same time so that it is, for example, possible to simulate the evolution of a given solute and one metabolite. For each solute, adsorption on the soil matrix is represented by linear (eq1) or Freundlich (eq2) adsorption isotherms:

$$
\begin{gathered}
q_{a d s}=K_{d} c \\
q_{a d s}=K_{f} c^{n_{f}}
\end{gathered}
$$

with $q_{a d s}$ the mass of solute adsorbed per mass of soil at the equilibrium $\left[\mathrm{MM}^{-1}\right], K_{d}$ the linear coefficient of adsorption $\left[\mathrm{L}^{3} \mathrm{M}^{-1}\right], K_{f}$ the Freundlich coefficient of adsorption $\left[\left(\mathrm{L}^{3}\right)^{n_{f}} \mathrm{M}^{1-n_{f}} \mathrm{M}^{-1}\right]$ and $n_{f}$ the exponent of Freundlich equation [-]. Influence of soil properties on adsorption is taken into account by correcting the adsorption coefficient with soil organic carbon content $f_{o c}[-]: K_{d}=K_{d o c} * f_{o c} / 100$ (resp. $\left.K_{f}=K_{f o c} * f_{o c} / 100\right)$ where $K_{d o c}\left(\right.$ resp. $K_{f o c}$ ) is the linear (resp. non-linear) organic carbon-water partition coefficient [-]. Degradation is integrated according to first-order kinetics:

$$
c(t)=c_{0} \exp (-k t)
$$

where $c_{0}$ is the concentration at time $0\left[\mathrm{ML}^{-3}\right]$ and $k$ the degradation rate $\left[\mathrm{T}^{-1}\right]$. The degradation rate is linked to the half-life $D T 50[\mathrm{~T}]$ by the relation : $k=\frac{\ln (2)}{D T 50}$. If a metabolite has been specified, the degraded quantity is added to the metabolite mass in each column cell. 


\subsubsection{Lateral saturated transfers on plots}

The PPI (Plot-Plot-Interface) unit has been developed to handle lateral transfers between two plots and more generally between two soil columns. As commonly done, it is assumed that lateral transfers are mainly saturated and that unsaturated flows can be neglected (Abbott et al., 1986, Chiew et al., 1992, Beckers \& Frind, 2000). PPI is based on the Darcy law (eq 4 ) and on a simplified parameter setting firstly established for the WTI (Water Table Interface) unit within the LIQUID framework (Branger et al., 2010). The LIQUID unit has been adapted to the specific needs of PESHMELBA, mostly linked to solutes. For example, shallow water tables must be taken into account as pesticide fate is fully dependent on the transport and transformation processes that take place in the near-surface soil layer (Flury et al. 1995). The PPI unit is therefore designed to handle heterogeneous soils composed of several horizons and multi-water-table cases with soil columns that simultaneously include groundwater and shallow water tables. Considering two connected soil columns $\operatorname{Col}_{x}$ and $\operatorname{Col}_{y}$, for each water table in $\operatorname{Col}_{x}$, the closest but lower water table in $\mathrm{Col}_{y}$ is identified (the bottom of the water table is taken as reference). If the hydraulic gradient between the two plots is compatible with the topographic gradient, a lateral saturated flow is determined between those water tables (Figure 3. (b) and (d)). Otherwise it is set to zero. If there is no water table in $\mathrm{Col}_{y}$, the saturated flow is calculated between the water table of $\mathrm{Col}_{x}$ and the lower cell of the closest but lower horizon in $\mathrm{Col}_{y}$ (Figure 3. (c)).

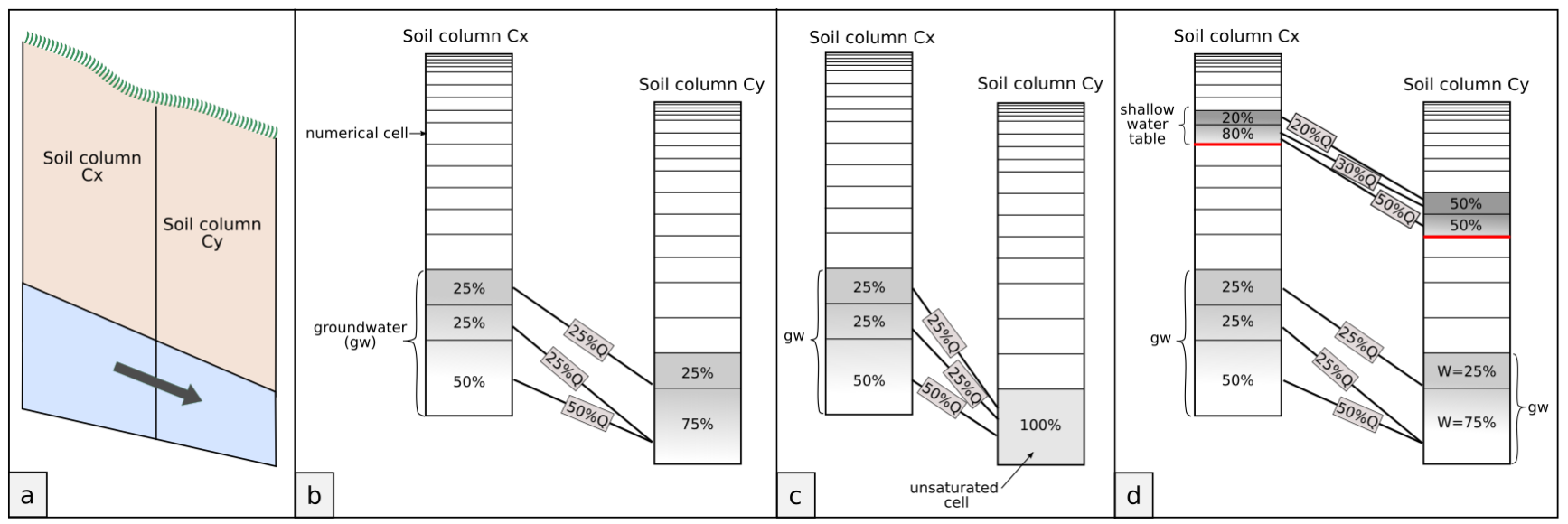

Figure 3: (a) Schematic view of two soil columns with water table. (b,c,d) Examples of distribution of the saturated flow calculated by PPI between saturated layers, (b) with transfer involving groundwater in the 2 plots, (c) with groundwater in one plot only, or (d) with groundwater and shallow water table. Red lines stand for interfaces between soil horizons and grey gradient stands for concentration gradient. Percentages within the numerical cells of each column are weights $w_{W T}^{i}$ that distribute the outgoing flow $Q$ toward each cell downstream. Percentages on connections between cells illustrate the contributions of each cell upstream to spread the outgoing flow $Q$ toward each cell downstream.

For each water table in $C o l_{x}$, the associated volumetric flow $Q_{x \rightarrow y}\left[\mathrm{~L}^{3} \mathrm{~T}^{-1}\right]$ is expressed as:

$$
Q_{x \rightarrow y}=K_{s, h}^{i n t} * A * \frac{H_{x}-H_{y}}{d_{x}-d_{y}}
$$

where $A$ is the contact area between the columns $\operatorname{Col}_{x}$ and $\operatorname{Col}_{y}\left[\mathrm{~L}^{2}\right], H_{x}$ and $H_{y}$ the water table levels in columns $\mathrm{Col}_{x}$ and $\mathrm{Col}_{y}[\mathrm{~L}], d_{x}$ and $d_{y}$ the distances between the centers of the columns and the interface [L] and where $K_{s, h}^{\text {int }}$ is the horizontal hydraulic conductivity at saturation at the interface [LT'-1] (see Appendix Appendix B.3.1 
for detailed calculation of $K_{s, h}^{i n t}$ ). The total saturated flow from $\mathrm{Col}_{x}$ to $\mathrm{Col}_{y}$ is the sum of the volumetric flows associated to each water table in $\mathrm{Col}_{x}$ and determined by eq. 4 In what follows, this flow will be considered positive from $\mathrm{Col}_{x}$ to $\mathrm{Col}_{y}$.

For each water table in $\mathrm{Col}_{x}$, a resulting solute flow is calculated standing for advective transport:

$$
Q_{x \rightarrow y}^{s o l}=c * Q_{x \rightarrow y}
$$

where $Q_{x \rightarrow y}^{s o l}$ is the solute mass flow $\left[\mathrm{MT}^{-1}\right]$ and $c$ the concentration of a given pesticide in the dissolved phase $\left[\mathrm{ML}^{-3}\right]$. PPI is based on the same vertical meshing than FRER1D so that the different lateral contributions will be used as sink/source term and handled by FRER1D without further adaptation when coupling the two units. As for vertical infiltration calculation, each soil column is divided in horizontal cells and an original coefficients system is applied to handle the spreading of the resulting flow $Q_{x \rightarrow y}$ between the saturated cells of the two columns. For each saturated transfer identified between $\mathrm{Col}_{x}$ and $\mathrm{Col}_{y}$, the coefficients system defines which portion of $Q_{x \rightarrow y}$ flows out from each saturated cell in $\mathrm{Col}_{x}$ and enters in each saturated cell in $\operatorname{Col}_{y}$. Those coefficients $w_{W T}^{i}$ are derived from the hydraulic conductivity and the thickness of each layer in order to prioritize the transfers between numerical cells with higher hydraulic conductivity or higher thickness. They are calculated for each water table so that the sum is equal to 1 within the water table (eq. B.13). Besides, if a water table exists in $\operatorname{Col}_{y}$, each cell from $\mathrm{Col}_{x}$ that contributes to the outgoing flow is associated to the closest cells of this water table in $\mathrm{Col}_{y}$. Such a technique should avoid complete mixing of a potential vertical gradient of concentration during lateral transfers.

\subsubsection{Surface runoff on plots}

Surface runoff corresponds to the water that did not have time to infiltrate or that exfiltrated within a time step. This quantity is determined by the FRER1D unit before being routed across the landscape by the newlydeveloped SURROM (SURface ROuting Module) unit. Classical approaches to handle surface runoff routing across a catchment are based on solutions of the kinematic wave equation (Beven, 1979, Li et al., 1975) or solutions of the diffusive wave equation (Moussa \& Bocquillon, 1996, Kraft et al., 2012, Gassmann et al., 2013: Camporese et al. 2010). However, the originality of the approach of PESHMELBA is the explicit inclusion of the linear elements of the landscape. Those elements intercept or redirect surface runoff along the watershed and would represent many tricky discontinuities to handle in a classical resolution of runoff routing. Moreover, as detailed previously, water available at surface for runoff for each plot is computed from FRER1D and a single height of water is affected to the plot. Regarding the constraints linked to the presence of discontinuities and to the meshing imposed by FRER1D, a sequential approach based on the kinematic wave approximation has been adopted. After running, FRER1D provides an excess surface water $h_{0}$ that did not infiltrate during the time step of the application (hereafter called dt_PALM). This water level is transmitted to SURROM that also runs during dt_PALM. However, as infiltration and surface runoff processes contrast by their characteristic duration, SURROM uses a smaller time step than FRER1D (called dt_RO). So SURROM runs several times between $t$ and $t+d t_{-} P A L M$ at its own time step $d t_{-} R O$. At each time step dt_RO, the water volume $\frac{d t_{-} P A L M}{d t_{-} R O} \times h_{0}$ is applied on the plot. Then, flux is calculated from water level with the Manning-Strickler equation. A corresponding outgoing water volume is determined and 
this volume has to be allocated to one or several downstream elements. The distribution between them is done considering a weighting system based on the length of the interface and the altitude gradient between the centroids of these two elements. If a given plot has $n$ downstream connections with surface or linear elements, the outgoing flow towards each downstream element $i \in\{1, \ldots, n\}$ is :

$$
Q_{i}=w_{i} \times \frac{L_{i} h_{w}^{5 / 3}}{n} \sqrt{S_{0}} \text { with } w_{i}=\frac{s^{i} L_{i}^{2 / 3}}{\sum_{j=1}^{n} s^{j}\left(L_{j}\right)^{2 / 3}}
$$

Where $L_{i}$ is the length of interface with the downstream element $i[\mathrm{~L}], h_{w}$ the water level on the plot [L], $n$ the Manning coefficient $\left[\mathrm{L} \mathrm{T}^{-1 / 3}\right], S_{0}$ the slope of the plot $\left[\mathrm{L} \mathrm{L}^{-1}\right]$ and $s^{i}$ the altitude gradient between the centroid of the plot and the connected element $i[-]$. Then, water level is updated considering the outgoing volume towards downstream elements (linear or surface) and the potential incoming volumes from upstream. Such a sequential approach does not require any calculation order as outgoing volume flows are calculated on all plots before updating water levels with downstream and upstream contributions.

In addition, the SURROM unit accounts for advective transport of solutes. Reactive transfers are also taken into account through simplified representations of degradation and adsorption. Degradation is simulated in the whole dissolved phase by a first-order degradation law (Equation 3). Adsorption isotherms are applied in a mixing layer in order to represent sorption to the soil particles. Such mixing layer includes the water height on surface and the upper part of the soil layer with a configurable height. The upper part of the soil that is considered in the mixing layer is assumed to be in suspension with the water, allowing a complete and instantaneous adsorption. The adsorption is calculated at the end of each time step, allowing remobilization of solute previously adsorbed. Ponding can also be taken into account with a customizable height. As it delays surface runoff activation, water residence time increases enhancing pesticide trapping on plot.

\subsubsection{Routing in the hydrographic network}

Routing of water and solutes in ditch and river networks is represented by an adapted version of the River1D unit (Branger et al., 2010), which is based on the 1D kinematic wave approximation resolved by a fourth order Runge-Kutta method (Cash \& Karp, 1990). This unit deals with ramified networks, confluences and has also been modified to handle diffluences, since those configurations can happen in complex ditch networks. The different reaches of ditches and rivers obtained from landscape analysis (cf section 2.1) are firstly gathered into independent networks. Each reach is represented with a simplified geometry based on a trapezoidal section. It receives lateral subsurface and surface input flows from connected neighboring elements. Additionally, solute transport is simulated in the network by solving the advection equation. Dispersion has not been included yet. Reactive solute transfers are represented by a first-order degradation law in the river and ditch reaches. Adsorption processes are also considered to the various materials of the ditch bed. It is assumed that sorption processes take place in a mixing layer of $2 \mathrm{~cm}$ at the bottom of the ditch. This is a strong but common hypothesis assumption in modeling approaches (Focus, 2007; Dollinger, 2016). 


\subsubsection{Lateral exchanges between plots and linears}

210 subsurface flow between two plots separated by a reach of ditch (Figure 4). The lateral subsurface flow between two plots is firstly computed without considering the intersection by a linear element, as described Figure 3 . Then, the portion of flow generated in the numeric layers above the bottom of the ditch is driven to the ditch. The rest of the flow is transferred to the plot downstream. This unit handles interception of flows from shallow water tables and from groundwater. Solutes dissolved in the water are similarly allocated as they are advected by the water flow.

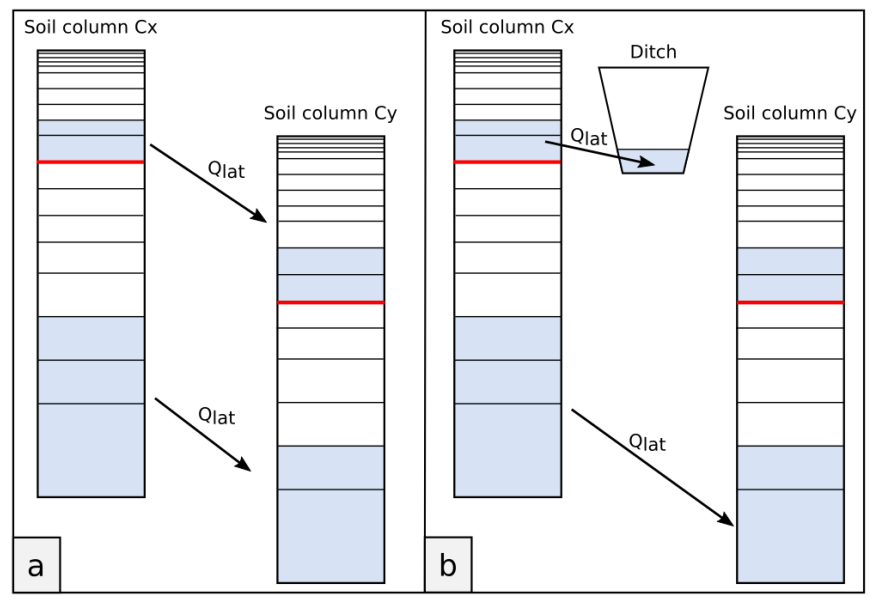

Figure 4: Procedure of calculation of flow interception by a ditch in the PDI unit. Red lines stand for interfaces between soil horizons. $Q_{\text {lat }}$ is the lateral subsurface flow between two saturated zones. (a) Lateral subsurface flows are firstly calculated without being intercepted by the ditch. (b) Then, part of the flows are allocated to the ditch.

It is also considered that river reaches intercept surface runoff generated on the plots upstream. Exchanges between groundwater and the river are expressed in the PRI unit (Plot-River-Interface) using the Miles relation (Miles, 1985):

$$
Q_{p r}=C_{m} K_{s} \Delta h
$$

where $Q_{p r}$ is the flow between the aquifer and the river $\left[\mathrm{L}^{3} \mathrm{~T}^{-1}\right] . Q_{p r}$ is directed to the river if superior to zero (respectively directed to the plot if inferior to zero). $K_{s}$ is the saturated hydraulic conductivity of the aquifer $\left[\mathrm{L} \mathrm{T}^{-1}\right], \Delta h$ is the head loss between the groundwater and the river [L] and $C_{m}$ the Miles coefficient adapted for trapezoidal section (Dehotin, 2007):

$$
C_{m}=\frac{0.5\left(0.25\left(W_{b}+W_{t}\right)+H_{r}+s\right)}{D+H_{r}+s}
$$

with $H_{r}$ is the river stage level [L], $D$ the saturated thickness of the aquifer below the river bed [L], $W_{b}$ the bottom width $[\mathrm{L}], W_{t}$ the water surface width $[\mathrm{L}]$ and $s$ the height of the seepage face [L]. $Q_{p r}$ is converted into a sink (respectively source) term for each numerical cell of the water table in the plot. Such calculation is based on the same splitting system as presented in Section 2.2.2. Solutes are also advected in direction to the river (respectively 
in direction to the plot). In case of a flow directed to the river, the outgoing solute flow from each cell is calculated using the water flow from this cell and the corresponding solute concentration. In case of a flow directed towards the plot, such lateral flow is determined using the water flow to each cell and the solute concentration in the river. Finally, shallow water tables can also flow towards the river through a seepage face. The outgoing flow is then determined using the lateral pressure gradient between the plot and the atmosphere.

\subsection{Coupling of processes and landscape elements with the OpenPALM coupler}

The elementary units presented in Section 2.2 are coupled in the OpenPALM software in order to build the PESHMELBA model (Figure 22. OpenPALM is an open-source dynamic coupler allowing for data exchanges be-

tween different independent code components through MPI (Message Passing Interface) communications (Duchaine et al. 2015). A specific feature of this tool is its ability to deal with complex execution scheduling and thus to address complex modeling issues. For the PESHMELBA building, the units are integrated within the framework according to their specific language (Fortran90 for PARTITION, ROOT, FRER1D and Python for PPI, PDI, SURROM, RIVER1D) and gathered depending on the type of element they refer to. Communications are set between units in order to transfer state variables, fluxes and forcing. Two time steps are used in a PESHMELBA simulation, all specified by the user. The first one is the global time step $d t$ PALM that can vary all along the simulation depending on weather conditions. This adaptive time step is finer during or after rainy periods (Figure 5 ) and it is used by all units relative to subsurface processes (PARTITION, ROOT, FRER1D, PPI and PDI). Other units that represent processes with distinct characteristic durations, such as SURROM or RIVER1D are solved on a second time step dt_RO, smaller than dt_PALM. The coupling is simplified by running the units with distinct time steps sequentially: first, the units PARTITION, ROOT and FRER1D are run between $\mathrm{t}$ and $\mathrm{t}+\mathrm{dt}$ _PALM. Then, the final ponding volume is transferred from FRER1D to SURROM. The SURROM unit is launched between $t$ and $t+$ $\mathrm{dt} \_$PALM and runs several times as long as it characteristic time step dt_RO is smaller than dt_PALM (Figure 5). At each time step dt_RO, a fraction of the ponding volume recovered from FRER1D is allocated to SURROM to calculate surface runoff. Sequentially, the surface runoff variable is sent to the RIVER1D unit to calculate the flow in the different networks. RIVER1D also runs several times between $\mathrm{t}$ and $\mathrm{t}+\mathrm{dt}$ _PALM with its characteristic time step dt_RO. Once the execution of the SURROM and the RIVER1D units between $\mathrm{t}$ and $\mathrm{t}+\mathrm{dt}$ _PALM are over, the PPI and PDI units calculate the lateral subsurface flows that will be used at the following time step $\left(\mathrm{t}+\mathrm{dt} \_\right.$PALM $)$.

\section{PESHMELBA application cases}

\subsection{Scenarios set up}

In order to assess the coupling, PESHMELBA was tested on 4 contrasted scenarios of growing complexity (see figure 6). Scenario 1 was based on a setup including two 1-ha plots connected through a 100-m interface. Scenario 2 integrated a reach of ditch between Plot 1 and Plot 2, and a second reach, longitudinally connected to the first one. A second set of scenarios aimed at evaluating the model in more complex scenarios involving more connections at surface and subsurface. For that purpose, a virtual hillslope of 11.2 ha was set. Scenario 3 was first composed of plots and rivers and Scenario 4 considered the presence of a network of ditches on the same 


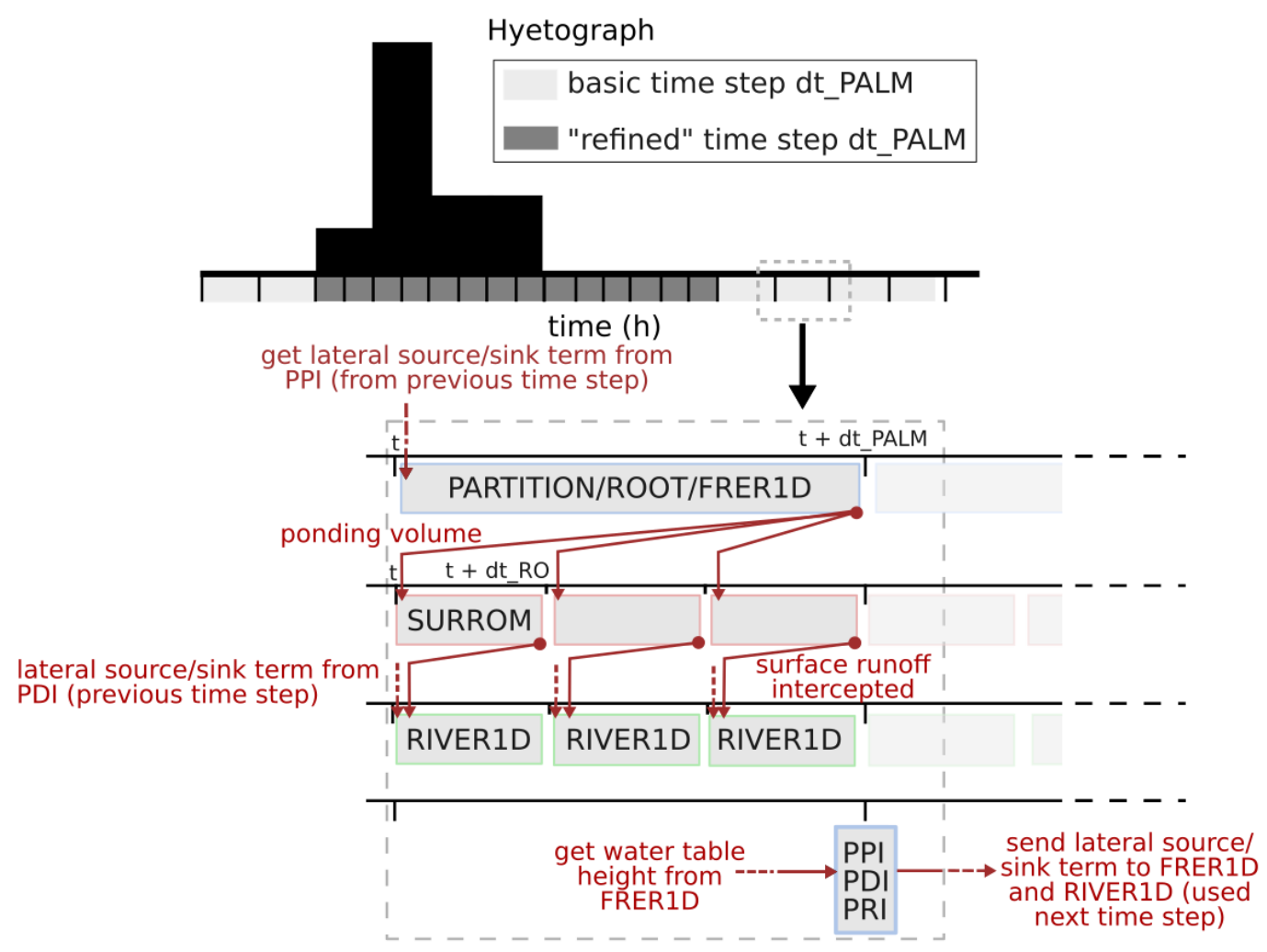

Figure 5: Timeline with time steps nesting and variable exchanges as implemented in PESHMELBA. Top: schematic hyetograph illustrating the refinement of $\mathrm{dt}$ _PALM considering the rainfall characteristics. Bottom : zoom on the units organization during one time step dt_PALM and on the use of an internal time step for surface runoff. Each grey rectangle stands for one unit execution and red arrows stand for variable exchanges within a time step dt_PALM. 
configuration. Simulations were run with very mobile, moderately mobile and slightly mobile solutes in order to investigate PESHMELBA capacities for representing transport and fate of solutes with contrasted properties. They involved Bromide (hereinafter referred to as $\mathrm{Br}^{-}$), Isoproturon (IPU) and Diflufenican (DFF) respectively.

\section{Scenario 1}

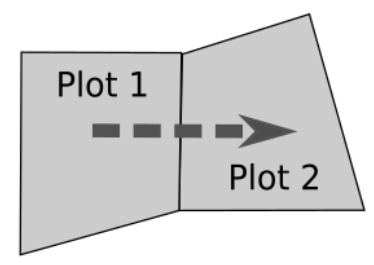

Scenario 3

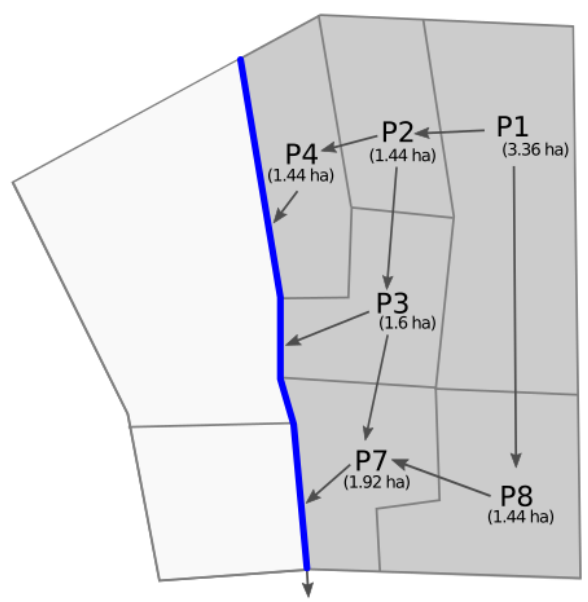

\section{Scenario 2}

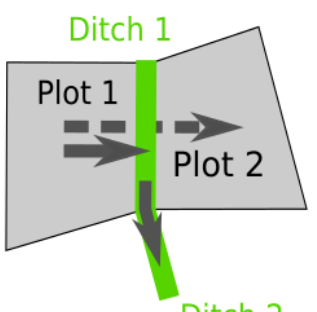

Scenario 4

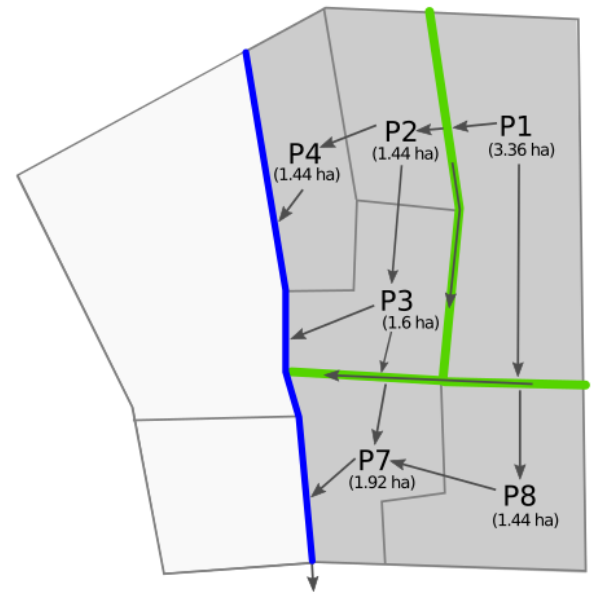

Figure 6: All configurations tested to assess PESHMELBA model locally (Scenarios 1 and 2) and then at the hillslope scale (Scenarios 3 and 4). Grey polygons stand for plots, blue lines stand for rivers and green lines stand for ditches. In Scenarios 3 and 4 , the hillslope is the right part of the domain.

For Scenario 1 and 2, results analysis focused in details on vertical information (saturation and solutes mass profiles) for each element and a complete mass balance was set to assess transfers between them. We particularly intended to investigate lateral exchanges involving shallowly perched water table. Comparisons between Scenario 1 and 2 were performed to assess the impact of a ditch implantation on solute transfers at a local scale but also the behavior of contrasted molecules in these two configurations. In Scenario 2, we also aimed at examining interception of subsurface flow by a ditch and longitudinal transfer of water and solutes along a network of ditches. Considering the number of elements involved in Scenarios 3 and 4, the model application was assessed through spatialized results. Mass balance at the hillslope scale and exportation rate at the outlet were also provided to assess the impact of the ditch network on pesticide exportation. Again, simulations were run with IPU, DFF and $\mathrm{Br}^{-}$to discuss the influence of solute characteristics on pathways and exported masses. Finally, for all scenarios, mass balance error was carefully examined as it is a basic but crucial indicator of model performances. 


\begin{tabular}{cccc}
\hline Parameter & Unit & Ditch & River \\
\hline \hline Depth & $\mathrm{m}$ & 0.5 & 2.0 \\
Bank angle & $\circ$ & 30 & 10 \\
Bottom width & $\mathrm{m}$ & 0.5 & 2.0 \\
Slope & $\%$ & $2 / 0.2$ & 0.2 \\
Soil thickness for adsorption & $\mathrm{m}$ & 0.04 & 0.02 \\
Saturated hydraulic conductivity of the aquifer & $\mathrm{m} / \mathrm{s}$ & - & $5.610^{-9}$ \\
Thickness of the aquifer below the river bed & $\mathrm{m}$ & - & 2.0 \\
\hline Bulk density & $\mathrm{g} / \mathrm{cm}^{3}$ & 1.4 & 1.4 \\
$\theta_{s}$ & - & 0.36 & 0.41 \\
Manning coefficient & $\mathrm{s} / \mathrm{m}^{1 / 3}$ & 0.03 & 0.033 \\
Input flow & $\mathrm{m} / \mathrm{s}$ & - & 0.08 \\
\hline
\end{tabular}

Table 1: Parameters of simulation for ditch and river reaches.

\subsection{General model setup}

The scenarios involved landscape elements which characteristics are based on the Kervidy catchment Cheverry, 1998; Carluer \& Marsily, 2004) in order to keep the application cases realistic. Although in PESHMELBA each the same for each element type. Each plot was discretized into 19 vertical cells of growing thickness from $0.5 \mathrm{~cm}$ at the top of the column to $50 \mathrm{~cm}$ at the bottom. Soil columns were $4 \mathrm{~m}$ high with a $2 \%$ surface slope and a ponding height threshold of $0.25 \mathrm{~cm}$ on surface. Soil type was an hydromorphic soil (Carluer \& Marsily, 2004), with a 2-cm soil crusting layer characterized by lower permeability and higher bulk density (Table 2). Anisotropy between vertical and horizontal hydraulic conductivity at saturation was also considered $\left(\gamma=K_{\text {sat }}^{h} / K_{\text {sat }}^{v}=10\right)$. Ditches were $50-\mathrm{cm}$-depth, with an average slope equal to $2 \%$ if they were oriented in the flow direction and equal to $0.2 \%$ if they intercepted the flow direction. River reaches were all characterized by a $2 \mathrm{~m}$-depth and a slope of $0.2 \%$. Ditches and river characteristics are gathered in Table 1.

Atmospheric forcing was set according to Kervidy climatic conditions in the early spring. A strong stormy rainfall event of 3 hours had been extracted from Carluer \& Marsily (2004). It was characterized by a maximum rate of precipitation of $26.6 \mathrm{~mm} / \mathrm{h}\left(7.410^{-6} \mathrm{~m} / \mathrm{s}\right)$ reached during 1 hour and a total amount of $45.9 \mathrm{~mm}$. The evaporation rate was set at $0.2 \mathrm{~mm} / \mathrm{h}\left(4.710^{-8} \mathrm{~m} / \mathrm{s}\right)$. All simulations started 9 hours before the beginning of the rainfall event. Wheat crop in spring season was considered, corresponding to a 3-leaves stage of development. The parameter settings relative to vegetation processes were based on (Campbell, 1985, Li et al., 2001, Lammoglia et al. 2017) and described in detail Table C.7. All simulations ran for 10 days with an hourly time step. This time step was refined to 0.5 hour during the rain event and during 3 more hours after. IPU was firstly simulated and occurrence of Desmethylisoproturon (DM-IPU), the first metabolite of IPU (Gaillardon \& Sabar, 2006; Lewis et al. 2016) was considered. Then, simulations were run considering application of $\mathrm{DFF}$ and $\mathrm{Br}^{-}$. Solutes properties are 


\begin{tabular}{ccccccc}
\hline Parameter & Unit & \multicolumn{5}{c}{ Horizons } \\
\hline \hline Lower limit (from surface) & $\mathrm{m}$ & 0.02 & 0.1 & 0.3 & 0.7 & 4.0 \\
$\mathrm{~K}_{\mathrm{s}}$ & $\mathrm{m} / \mathrm{s}$ & $6.910^{-7}$ & $2.410^{-5}$ & $1.010^{-6}$ & $1.710^{-6}$ & $1.310^{-6}$ \\
$\mathrm{~K}_{\mathrm{s}}$ & $\mathrm{mm} / \mathrm{h}$ & 2.5 & 86.4 & 3.6 & 6.1 & 4.7 \\
$\theta_{r}$ & - & 0.14 & 0.14 & 0.00 & 0.00 & 0.00 \\
$\theta_{s}$ & - & 0.55 & 0.55 & 0.40 & 0.44 & 0.43 \\
$\mathrm{~h}_{\mathrm{e}}$ & $\mathrm{m}$ & -1.00 & -1.00 & -0.63 & -0.53 & -1.00 \\
$\lambda$ & - & 0.55 & 0.55 & 0.25 & 0.16 & 0.29 \\
Bulk density & $\mathrm{g} / \mathrm{cm}^{3}$ & 1.6 & 1.4 & 1.4 & 1.4 & 1.4 \\
Organic carbon content & $\%$ & 2.36 & 2.36 & 0.17 & 0.26 & - \\
Dispersivity & $\mathrm{m}$ & 0.2 & 0.2 & 0.2 & 0.2 & 0.2 \\
\hline
\end{tabular}

Table 2: Hydrodynamic properties of the hydromorphic soil profile used on plots.

\begin{tabular}{ccccc}
\hline & Units & Isoproturon & Desmethylisoproturon & Diflufenican \\
\hline \hline $\mathrm{DT}_{50}$ & $\mathrm{~d}$ & 12 & 33 & 94.5 \\
$\mathrm{~K}_{\mathrm{foc}}$ & $\mathrm{mL} / \mathrm{g}^{1}$ & 122 & 147 & 2215 \\
$\mathrm{n}_{\mathrm{f}}$ & - & 1.25 & 1.11 & 1.15 \\
\hline
\end{tabular}

Table 3: Properties of solute simulated provided by the Pesticide Properties Database - PPDB Lewis et al. 2016.

gathered in Table 3

\subsection{Initial and boundary conditions}

For all scenarios, hydrostatic equilibrium was assumed as initial condition for plots and an initial 2-m-height groundwater was considered. Ditches initially did not contain water and initial level of water was $0.12 \mathrm{~m}$ in rivers. No solute was initially present in plots nor in ditches or rivers. For Scenario 1 and Scenario 2, upstream boundary condition was a constant flow on the subsurface $\left(5.210^{-6} \mathrm{~m}^{3} / \mathrm{s}\right)$. Downslope lateral boundary was a Dirichlet condition given by connecting a virtual column with a fixed hydraulic head (2m-deep water table). For Scenarios 3 and 4, zero-flux was considered as boundary condition. Initial and boundary conditions for Scenarios 1 and 2 are gathered in Figure 7. For all scenarios, $1000 \mathrm{~g} / \mathrm{ha}$ of Isoproturon (IPU) was applied on Plot 1 at the beginning of the simulation (in Scenarios 3 and 4, it is equivalent to a total amount of $3360 \mathrm{~g}$ ). Note that for all scenarios, the same doses were considered for DFF and $\mathrm{Br}^{-}$, even if they are less realistic than for IPU, in order to compare simulations.

\footnotetext{
${ }^{1} \mathrm{~mL} / \mathrm{g}$ is the unit commonly used to describe Freundlich adsorption coefficient but it is actually a notation abuse and the actual unit is $(\mathrm{mL} / \mathrm{g})^{\mathrm{n}_{\mathrm{f}}}$
} 

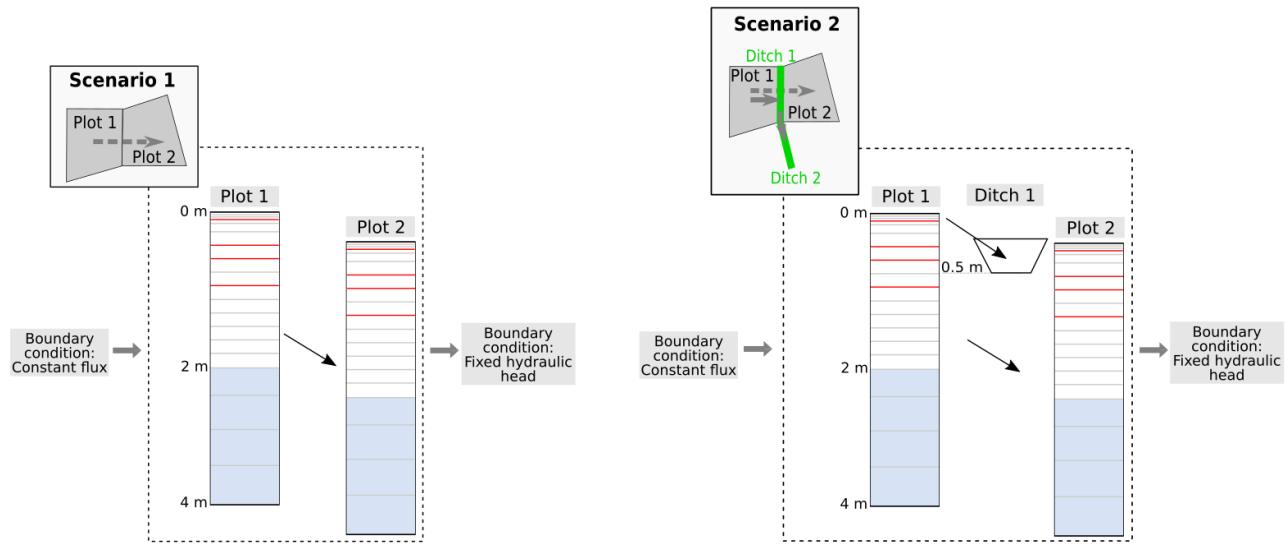

Figure 7: Vertical view and details on boundary and initial conditions for Scenarios 1 and 2.

\subsection{Results}

\subsubsection{Scenarios $1 \& 2$}

Table 4 reports the cumulative mass balance for Scenarios 1 and 2. The model was able to simulate contrasted dynamics of the two scenarios with an error on mass balance inferior to $10^{-10} \mathrm{~m}^{3}$ for water and inferior to $10^{-4} \mathrm{~g}$ for all solutes. In Scenario 2, the presence of a ditch reach didn't modify infiltration, evaporation and root extraction amounts on Plot 1 when comparing with Scenario 1. However, water and solute amounts that infiltrated on Plot 2 decreased with the presence of the ditch. Indeed, surface runoff generated due to the crusting layer on Plot 1 was transferred to Plot 2 in Scenario 1 whereas in Scenario 2, it was intercepted by Ditch 1. As shown in Figure 8 a shallow groundwater persisted in Plot 1 for both Scenarios 1 and 2 over the entire simulation leading to saturated subsurface transfers. The presence of a soil horizon with very low permeability between $10 \mathrm{~cm}$ and $30 \mathrm{~cm}$ in the soil profile also led to accumulation of infiltrated water. After $13.5 \mathrm{~h}$ of simulation, it led to formation of a shallowly perched water table associated to lateral transfers in both scenarios. What's more, this water table formed near the surface, in an area of high concentration in solutes (infiltrated from the surface). As a result, even if water volume transferred through this perched water table was quite low, a high quantity of solutes was transmitted. In Scenario 1, subsurface transfers were exclusively directed to Plot 2 but in Scenario 2, Ditch 1 intercepted water and solute transferred from shallowly perched water table. As a result, in Scenario 1, the solute profiles were characterized by high concentration near the surface for Plot 1 and Plot 2 (Figure 9, left and Figure 10, left). In Scenario 2, Plot 1 was characterized by the same profile evolution whereas Plot 2 only presented low solutes mass in the groundwater (Figure 9 right). In that case, small amounts of solutes percolated to groundwater in Plot 1 and were transmitted to Plot 2. As shown when comparing solute mass profiles (Figure 10) or mass balance (Table 4), mobile solutes such as $\mathrm{Br}^{-}$are mainly transferred both vertically and laterally whereas non-mobile solutes such as DFF remain concentrated close to the area of application.

\subsubsection{Scenarios 3834}

In both cases, the small hillslope reacted quite similarly in terms of water discharge. It responded very quickly to the rain event, with a peak of discharge of nearly $0.18 \mathrm{~m}^{3} / \mathrm{s}$ of water 2 hours after the beginning of the stormy event. However, solute transfer to the outlet was highly increased by the presence of the ditch network. Not only 

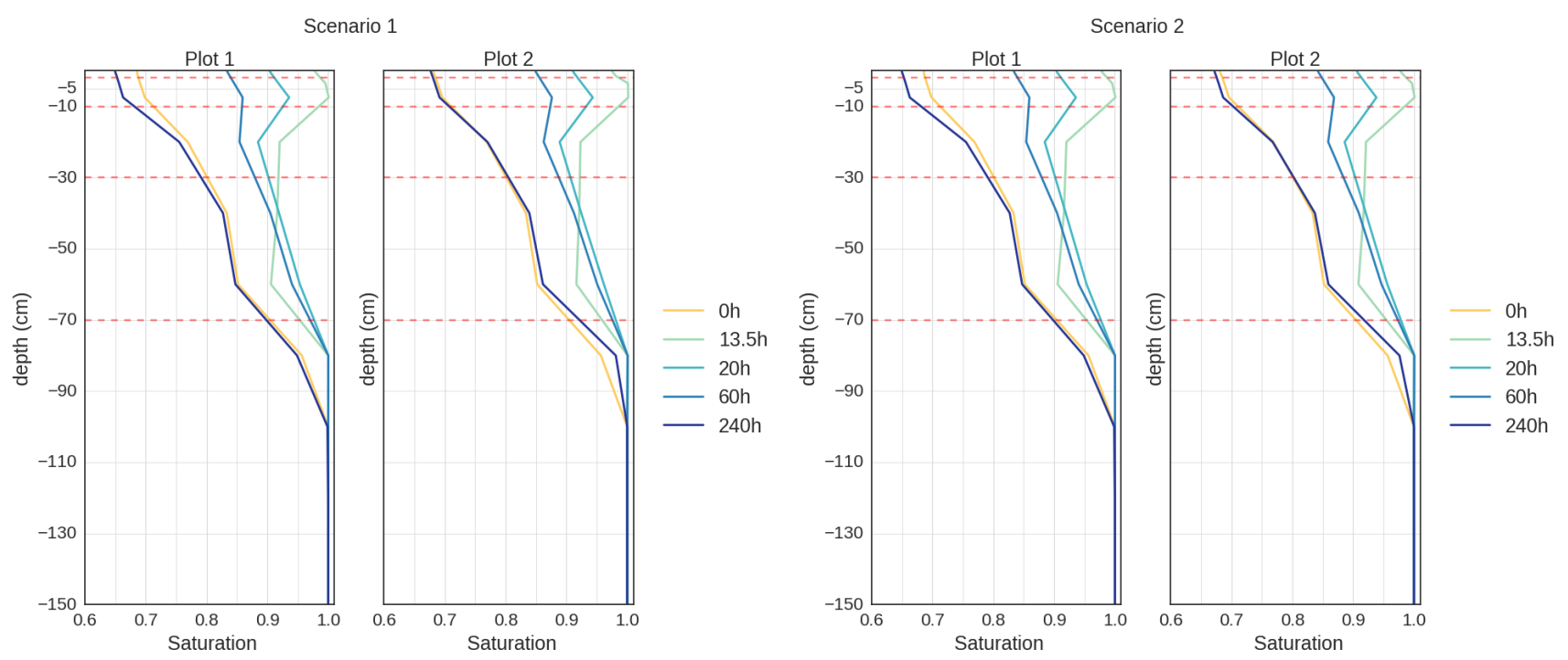

Figure 8: Saturation profile in the 2 plots at 13.5 h, 20 h, 60 h, and $240 \mathrm{~h}$ after the beginning of the simulation. Horizontal, dotted lines stand for interfaces between soil horizons.
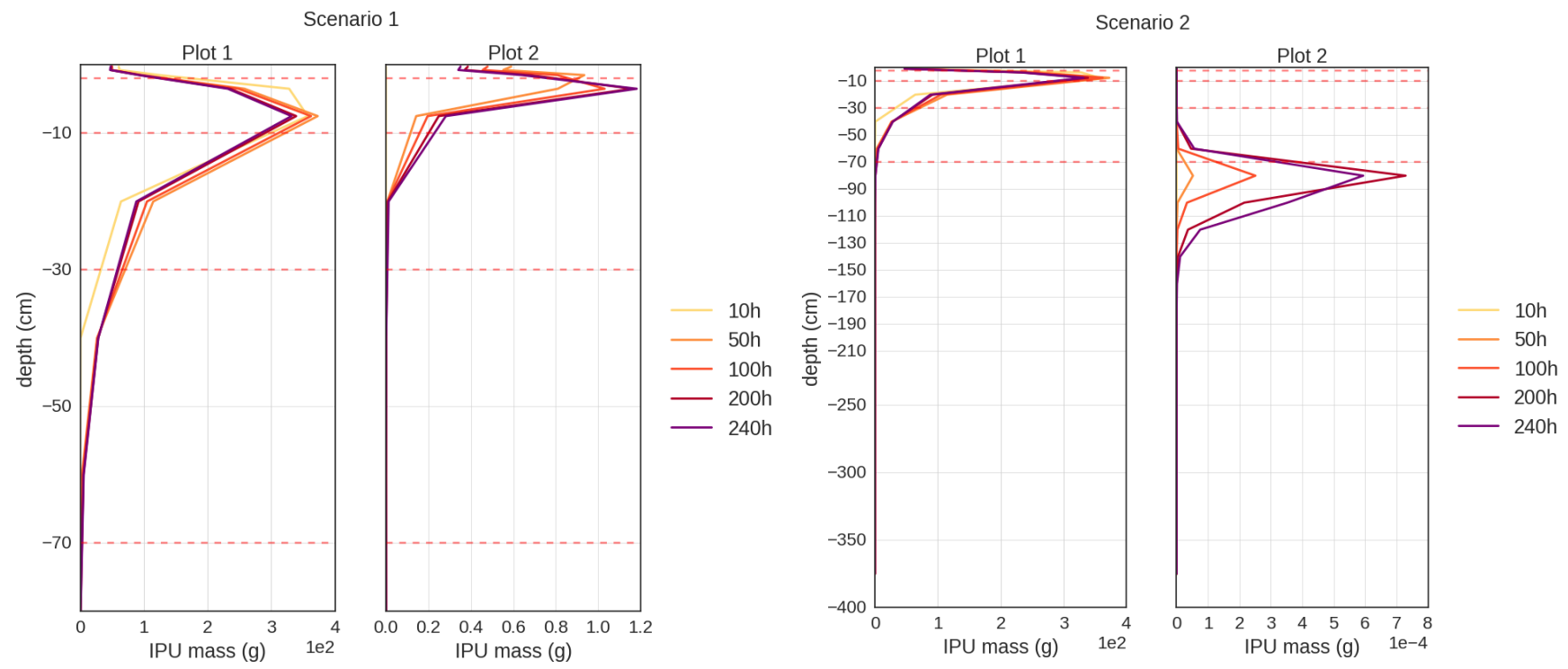

Figure 9: IPU mass profile in the 2 plots at 10 h, 50 h, 100 h, $200 \mathrm{~h}$ and $240 \mathrm{~h}$ after the beginning of the simulation. Horizontal, dotted lines stand for interfaces between soil horizons. To make the figure more readable, the vertical and horizontal axis change from a profile to another. 


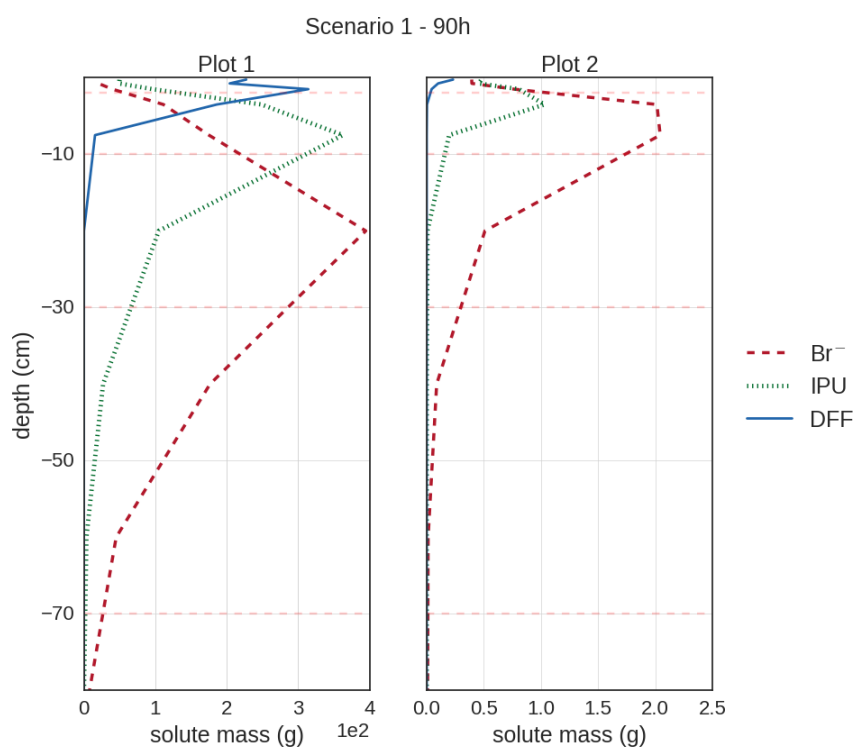

Figure 10: Comparison of mass solute profiles in Plots 1 and 2 after 90h of simulation for IPU, DFF and Br- for Scenario 1. 
Author-produced version of the article published in Science of The Total Environment,

Volume 671, 2019, Pages 1144-1160.

The original publication is available at https://www.sciencedirect.com/

doi : 10.1016/j.scitotenv.2019.03.060

Unit Infiltration Evaporation Root Extraction Surface Runoff

Subsurface transfer

Longitudinal transfer Shallowly perched

water table

Groundwater

\begin{tabular}{|c|c|c|c|c|c|c|c|c|c|}
\hline \multirow{5}{*}{ 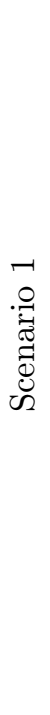 } & Water & $\mathrm{m}^{3}$ & $\begin{array}{l}346.0(\mathrm{P} 1) \\
359.0(\mathrm{P} 2)\end{array}$ & $\begin{array}{l}92.7(\mathrm{P} 1) \\
92.7(\mathrm{P} 2)\end{array}$ & $\begin{array}{l}338.4(\mathrm{P} 1) \\
338.3(\mathrm{P} 2)\end{array}$ & $\begin{array}{c}22.2 \\
(\mathrm{P} 1 \rightarrow \mathrm{P} 2)\end{array}$ & $\begin{array}{l}3.810^{-2} \\
(\mathrm{P} 1 \rightarrow \mathrm{P} 2)\end{array}$ & $\begin{array}{c}74.1 \\
(\mathrm{P} 1 \rightarrow \mathrm{P} 2)\end{array}$ & - \\
\hline & IPU & $\mathrm{g}$ & $\begin{array}{c}1003.5(\mathrm{P} 1) \\
3.1(\mathrm{P} 2)\end{array}$ & - & - & $\begin{array}{c}3.1 \\
(\mathrm{P} 1 \rightarrow \mathrm{P} 2)\end{array}$ & $\begin{array}{l}1.110^{-2} \\
(\mathrm{P} 1 \rightarrow \mathrm{P} 2)\end{array}$ & $\begin{array}{l}1.410^{-3} \\
(\mathrm{P} 1 \rightarrow \mathrm{P} 2)\end{array}$ & - \\
\hline & DM-IPU & $\mathrm{g}$ & $\begin{array}{l}7.510^{-3}(\mathrm{P} 1) \\
7.410^{-3}(\mathrm{P} 2)\end{array}$ & - & - & $\begin{array}{l}7.410^{-3} \\
(\mathrm{P} 1 \rightarrow \mathrm{P} 2)\end{array}$ & $\begin{array}{l}2.710^{-5} \\
(\mathrm{P} 1 \rightarrow \mathrm{P} 2)\end{array}$ & $\begin{array}{l}3.210^{-4} \\
(\mathrm{P} 1 \rightarrow \mathrm{P} 2)\end{array}$ & - \\
\hline & DFF & $\mathrm{g}$ & $\begin{array}{c}963.4(\mathrm{P} 1) \\
0.7(\mathrm{P} 2)\end{array}$ & - & - & $\begin{array}{c}1.2 \\
(\mathrm{P} 1 \rightarrow \mathrm{P} 2)\end{array}$ & $\begin{array}{l}1.410^{-4} \\
(\mathrm{P} 1 \rightarrow \mathrm{P} 2)\end{array}$ & $\begin{array}{l}9.410^{-9} \\
(\mathrm{P} 1 \rightarrow \mathrm{P} 2)\end{array}$ & - \\
\hline & $\mathrm{Br}^{-}$ & $\mathrm{g}$ & $\begin{array}{c}1007.2(\mathrm{P} 1) \\
6.2(\mathrm{P} 2)\end{array}$ & - & - & $\begin{array}{c}6.2 \\
(\mathrm{P} 1 \rightarrow \mathrm{P} 2)\end{array}$ & $\begin{array}{l}3.510^{-2} \\
(\mathrm{P} 1 \rightarrow \mathrm{P} 2)\end{array}$ & $\begin{array}{l}3.810^{-2} \\
(\mathrm{P} 1 \rightarrow \mathrm{P} 2)\end{array}$ & - \\
\hline \multirow{5}{*}{ 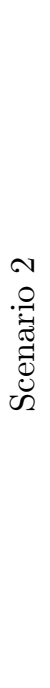 } & Water & $\mathrm{m}^{3}$ & $\begin{array}{l}346.0(\mathrm{P} 1) \\
347.0(\mathrm{P} 2)\end{array}$ & $92.7(\mathrm{P} 1)$ & $\begin{array}{l}338.4(\mathrm{P} 1) \\
338.4(\mathrm{P} 2)\end{array}$ & $\begin{array}{c}22.2 \\
(\mathrm{P} 1 \rightarrow \mathrm{D} 1)\end{array}$ & $\begin{array}{l}3.410^{-2} \\
(\mathrm{P} 1 \rightarrow \mathrm{D} 1)\end{array}$ & $\begin{array}{c}74.3 \\
(\mathrm{P} 1 \rightarrow \mathrm{P} 2)\end{array}$ & $\begin{array}{c}24.0 \\
(\mathrm{D} 1 \rightarrow \mathrm{D} 2)\end{array}$ \\
\hline & IPU & g & $\begin{array}{c}1003.5(\mathrm{P} 1) \\
0.0(\mathrm{P} 2)\end{array}$ & - & - & $\begin{array}{c}3.1 \\
(\mathrm{P} 1 \rightarrow \mathrm{D} 1)\end{array}$ & $\begin{array}{l}1.110^{-2} \\
(\mathrm{P} 1 \rightarrow \mathrm{D} 1)\end{array}$ & $\begin{array}{l}1.410^{-3} \\
(\mathrm{P} 1 \rightarrow \mathrm{P} 2)\end{array}$ & $\begin{array}{c}2.7 \\
(\mathrm{D} 1 \rightarrow \mathrm{D} 2)\end{array}$ \\
\hline & DM-IPU & $\mathrm{g}$ & $\begin{array}{c}7.510^{-3}(\mathrm{P} 1) \\
0.0(\mathrm{P} 2)\end{array}$ & 一 & 一 & $\begin{array}{l}7.310^{-3} \\
(\mathrm{P} 1 \rightarrow \mathrm{D} 1)\end{array}$ & $\begin{array}{l}2.410^{-5} \\
(\mathrm{P} 1 \rightarrow \mathrm{D} 1)\end{array}$ & $\begin{array}{l}3.210^{-4} \\
(\mathrm{P} 1 \rightarrow \mathrm{P} 2)\end{array}$ & $\begin{array}{c}9.010^{-3} \\
(\mathrm{D} 1 \rightarrow \mathrm{D} 2)\end{array}$ \\
\hline & $\mathrm{DFF}$ & $\mathrm{g}$ & $\begin{array}{c}963.4(\mathrm{P} 1) \\
0.0(\mathrm{P} 2)\end{array}$ & 一 & - & $\begin{array}{c}1.2 \\
(\mathrm{P} 1 \rightarrow \mathrm{D} 1)\end{array}$ & $\begin{array}{l}1.210^{-4} \\
(\mathrm{P} 1 \rightarrow \mathrm{D} 1)\end{array}$ & $\begin{array}{l}9.410^{-9} \\
(\mathrm{P} 1 \rightarrow \mathrm{P} 2)\end{array}$ & $\begin{array}{c}1.05 \\
(\mathrm{D} 1 \rightarrow \mathrm{D} 2)\end{array}$ \\
\hline & $\mathrm{Br}^{-}$ & g & $\begin{array}{c}1007.2(\mathrm{P} 1) \\
0.0(\mathrm{P} 2)\end{array}$ & - & - & $\begin{array}{c}6.2 \\
(\mathrm{P} 1 \rightarrow \mathrm{D} 1)\end{array}$ & $\begin{array}{l}3.310^{-2} \\
(\mathrm{P} 1 \rightarrow \mathrm{D} 1)\end{array}$ & $\begin{array}{l}3.810^{-2} \\
(\mathrm{P} 1 \rightarrow \mathrm{P} 2)\end{array}$ & $\begin{array}{c}5.8 \\
(\mathrm{D} 1 \rightarrow \mathrm{D} 2)\end{array}$ \\
\hline
\end{tabular}

Table 4: Mass balance for Scenarios 1 and 2. P1 stands for Plot 1, P2 for Plot 2, D1 for Ditch 1 and D2 for Ditch 2. 
the linear network dramatically increased the total amount of solutes transferred to the outlet $\left(3.610^{-3} \mathrm{~g}\right.$ of IPU in Scenario 3 vs $8.5 \mathrm{~g}$ in Scenario 4) but it also affected the contributions of the different transfer paths to the attenuation on such an event.
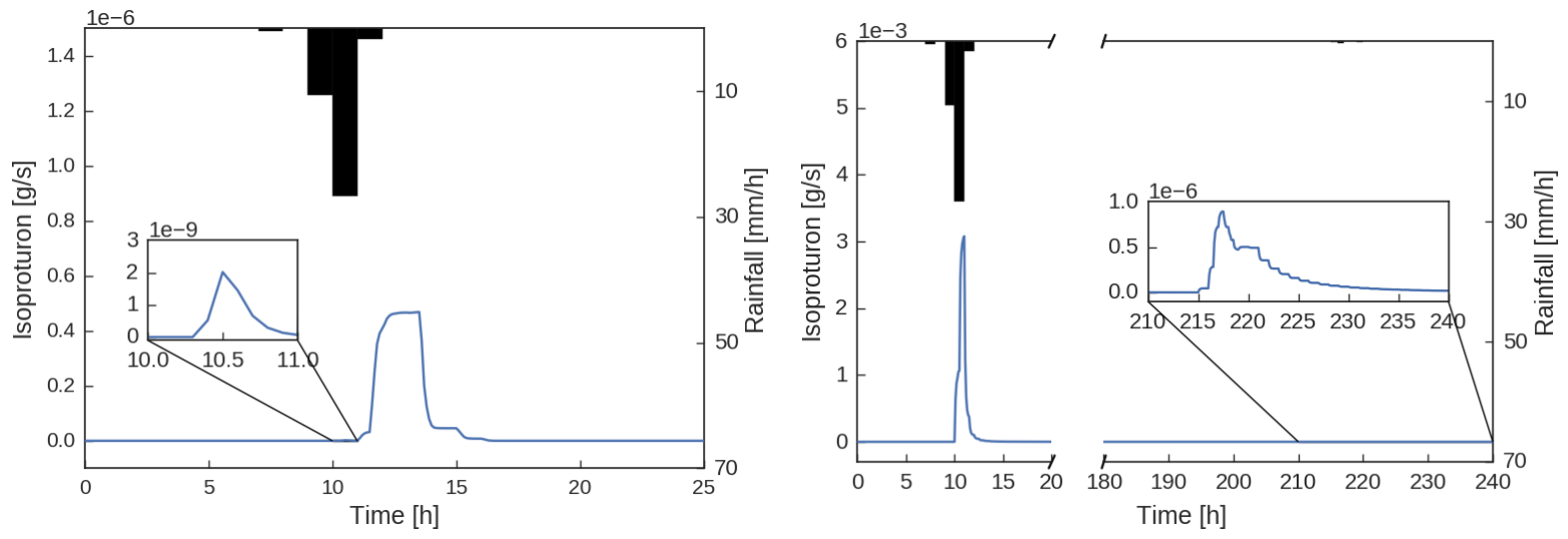

Figure 11: IPU discharge at the outlet of hillslope for Scenario 3 (left) and Scenario 4 (right). Rectangles in the figures represent zooms on the discharge for given periods of time.

Figure 12 reports for each scenario the evolution of IPU mass in each plot and ditch reach over time at surface and subsurface and all relative cumulative amounts are reported in Table 5 . Scenarios 3 and 4 ran with a final error on mass balance less than $10^{-8} \mathrm{~m}^{3}$ for water and less than $10^{-4} \mathrm{~g}$ for all solutes. Global mass balances and spatialized views of solute spreading over time show that transfer paths were also highly modified with the implantation of ditches. In Scenario 3, solutes spread quickly at the surface and the neighbouring plots were highly contaminated shortly after the beginning of the rain. The mass at surface decreased along time as the IPU infiltrated or was degraded. In the subsurface, IPU spread more slowly, mostly due to shallowly perched water tables that appeared because of the impermeable soil layer between $10 \mathrm{~cm}$ and $30 \mathrm{~cm}$. As no diffusion is considered when modeling lateral transfers between plots, it led to strong temporal and spatial discontinuities for solute masses. On the contrary, in Scenario 4, all surface runoff or subsurface transfer from shallowly perched water table generated in Plot 1 was intercepted by the ditch network. Most of solutes intercepted by the ditch network were quickly transmitted to 
the river while a small fraction remained adsorbed at the bottom of the ditch. Small amounts still transferred to between IPU, DFF and $\mathrm{Br}^{-}$for scenario 4. As for scenario 1, mobile solutes such as $\mathrm{Br}^{-}$are quickly transferred over the hillslope whereas non-mobile solutes such as DFF are poorly transfered from the zone of application. Mass balances gathered in Table 5 also illustrate such contrasted behaviors. For example, for all runs of Scenario 4, lateral flow intercepted at surface or subsurface by the ditch network mainly contributed to solute export to the outlet. However, amount of $\mathrm{Br}^{-}$exported to the outlet is nearly twice as much as IPU exported amount and it is nearly six times as much as DFF exported amount.

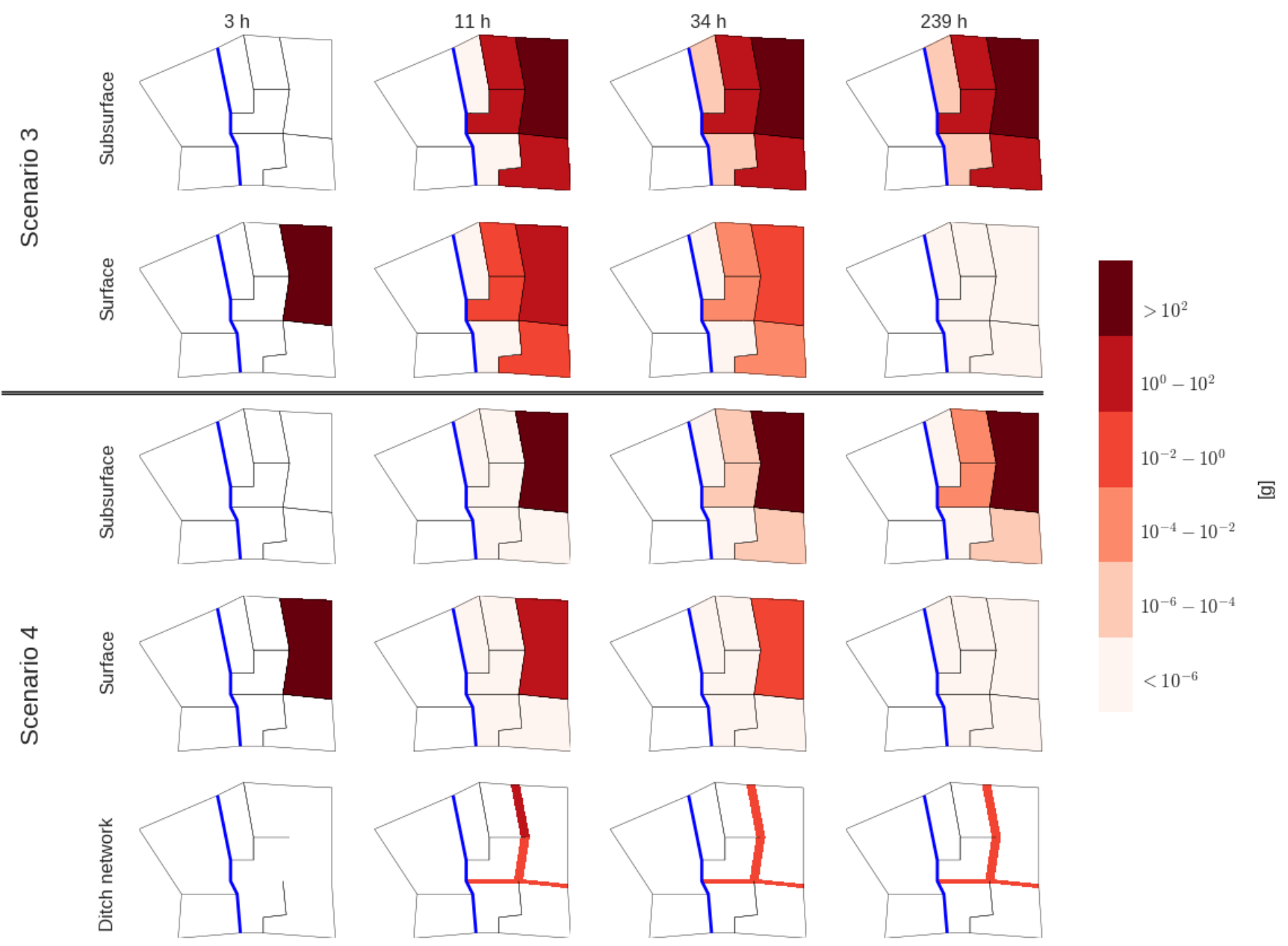

Figure 12: IPU mass along time over the hillslope for Scenarios 3 and 4 .

\section{Discussion}

In these first simulations, the main processes observed on the Kervidy catchment are successfully represented: formation of shallowly perched water tables and interception of subsurface transfers by ditch. Contrasted dynamics are simulated and show a clear effect of the presence of ditches that redirect and accelerate surface but also subsurface solute fluxes. Adsorption and degradation are properly represented by the model. They are simulated here with 


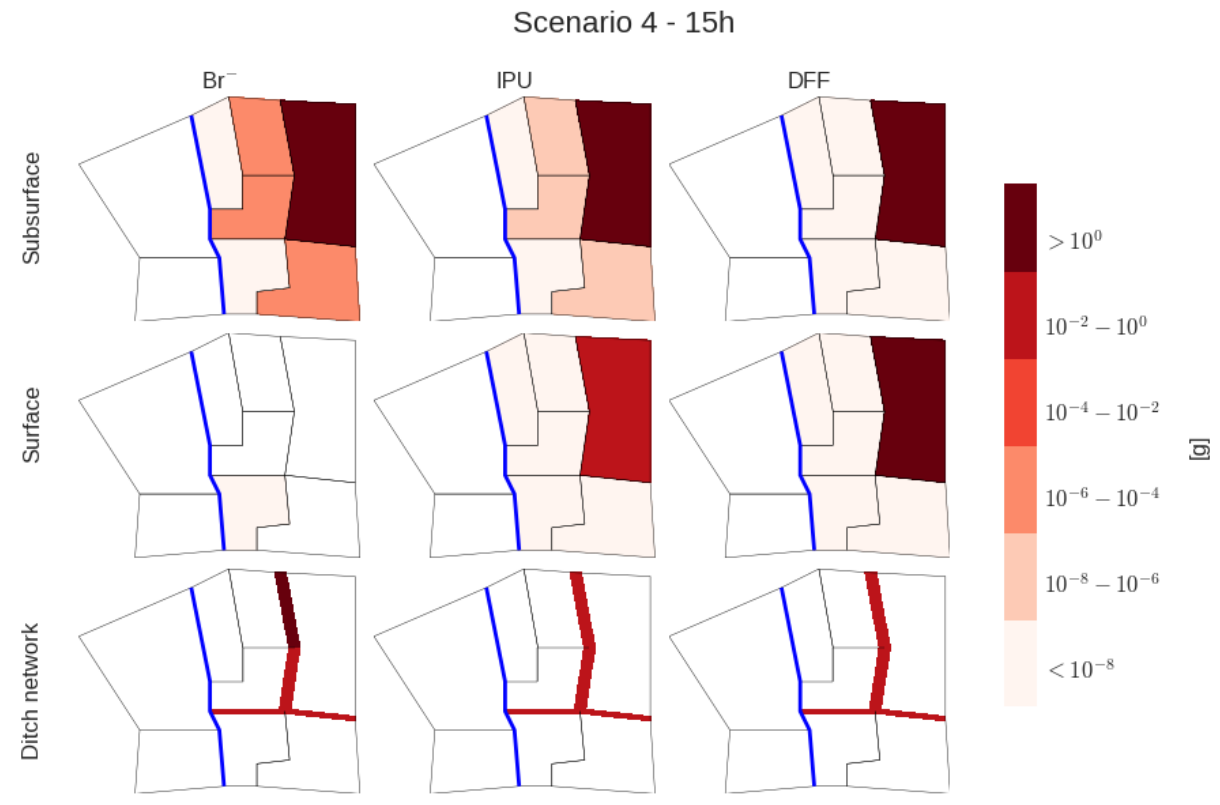

Figure 13: Comparison of mass spreading over the hillslope after 15h of simulation for IPU, DFF and $\mathrm{Br}^{-}$for $\mathrm{Scenario}^{-}$.

\begin{tabular}{|c|c|c|c|c|c|c|}
\hline & & Unit & $\begin{array}{l}\text { Surface runoff } \\
\text { to river }\end{array}$ & $\begin{array}{l}\text { Lateral saturated } \\
\text { transfer to river }\end{array}$ & $\begin{array}{l}\text { Transmitted by } \\
\text { ditch network }\end{array}$ & $\begin{array}{l}\text { Transmitted } \\
\text { to the outlet }\end{array}$ \\
\hline \multirow{5}{*}{ Scenario 3} & Water & $\mathrm{m}^{3}$ & 71.5 & $9.710^{-2}$ & - & $7.110^{4}$ \\
\hline & Mass of IPU & $\mathrm{g}$ & $1.810^{-6}$ & $3.010^{-3}$ & - & $3.610^{-3}$ \\
\hline & Mass of DM-IPU & $\mathrm{g}$ & $1.110^{-9}$ & $3.410^{-6}$ & - & $3.410^{-6}$ \\
\hline & Mass of DFF & $\mathrm{g}$ & $5.710^{-9}$ & $2.110^{-6}$ & - & $2.110^{-6}$ \\
\hline & Mass of $\mathrm{Br}^{-}$ & $\mathrm{g}$ & $2.210^{-5}$ & $8.410^{-2}$ & - & $8.410^{-2}$ \\
\hline \multirow{5}{*}{ Scenario 4} & Water & $\mathrm{m}^{3}$ & 63.9 & $9.610^{-2}$ & 77.2 & $7.110^{4}$ \\
\hline & Mass of IPU & $\mathrm{g}$ & 0 & $5.610^{-7}$ & 8.5 & 8.5 \\
\hline & Mass of DM-IPU & $\mathrm{g}$ & 0 & $1.710^{-7}$ & $2.710^{-2}$ & $2.710^{-2}$ \\
\hline & Mass of DFF & $\mathrm{g}$ & 0 & $3.810^{-12}$ & 3.0 & 3.0 \\
\hline & Mass of $\mathrm{Br}^{-}$ & $\mathrm{g}$ & 0 & $1.710^{-5}$ & 17.6 & 17.6 \\
\hline
\end{tabular}

Table 5: Cumulative amounts of water and solutes transferred to outlet through the different pathways at the end of simulations for Scenarios 3 and 4 . 
parameters from the Pesticide Properties Database - PPDB (Lewis et al. 2016) as field data were lacking. However, such parameters are obtained in laboratory or for given field conditions and do not allow for taking into account specific soil properties from the field of application. If field data are available, users can include them in the model for better catching soil-dependency and spatial variability of those processes. In the same way, formation of metabolite is successfully represented. For these simulations, DM-IPU was considered as the only metabolite with a $100 \%$ occurrence fraction to test the feasibility of integrating metabolite fate in the model. This simplistic representation can evolve in more realistic application cases depending on the user's knowledge about metabolite formation and transformation. Finally, solutes with distinct properties and contrasted behaviors can also be simulated by the model but much longer simulations should be performed to assess properly DFF degradation that is characterized by a long half-life time.

Still, some processes and elements are currently represented in a simplistic way or are just missing in the model. Such choices are justified to illustrate dominant processes on the catchment chosen for the first simulations and they can evolve thanks to PESHMELBA modular structure. Yet, one should keep in mind that such a tool aims at comparing and ranking landscape management scenarios for decision making rather than precisely predicting solute amounts at any point of the catchment. Actually, to our knowledge, no model is currently able to simulate those interactive processes at such a scale and under real field conditions. As a result, efforts made to improve the simulations should focus mainly on dominating processes that rule solute behavior at the catchment scale. For example, description of degradation in PESHMELBA currently does not take into account influence of temperature or soil moisture. The code can easily be modified to include such relations as the ones from Larsbo \& Jarvis (2003) for example. Additional developments should also depend on what the user knows about the functioning of the targeted catchment. In the application cases described in this paper, ditches functioning is limited to surface and subsurface flow interception. Such hypothesis is relevant in the case of the Kervidy catchment where ditches functioning is mainly drainage of water during wet season. It may be necessary to modify it in other contexts and to include infiltration within the ditch depending on its characteristics. More generally, other processes that play a key role on pesticide transfers should also be added such as macropore flow in soils (Beven \& Germann, 2013 Djabelkhir et al., 2017) or sediment transport (Muñoz-Carpena et al., 1999, Warren et al., 2003). Some of them can be included with mechanistic additive units, but they may also be added more simply with transfer functions (Jury \& Horton, 2004). It must be pointed out however that the model structure is limited to include diffusion although it would probably limit the discontinuities in solute mass due to spatial discretization.

Before reaching a complete representation of an agricultural watershed, other elements also need to be implemented. The implementation of buffer zones such as vegetative filter strips, hedges or artificial wetlands will be the next step to test different options for best management practices for transfers attenuation. Drained plots will also be included as they are commonly set up on agricultural watersheds. To that aim, we will use existing modeling knowledge such as Branger et al. (2009, 2010) for tile-drained plots, Krone-Davis et al. (2013) for wetlands or Lauvernet \& Muñoz-Carpena (2018) for buffer zones. Metamodeling approaches (Villa-Vialaneix et al., 2012, Lauvernet et al. 2016) can also be used to simplify units based on mechanistic models, to limit the number of input parameters and to make the numerical cost reasonable. Indeed, these application cases show that the calculation time of the model may become a problem when making more complex scenarios (calculation time increased from 108s in Scenario 1 
to 1285 s in Scenario 4). In order to explore different scenarios of landscape organization efficiently, it is crucial to optimize the calculation time of the model. The River1D unit that handles routing in the network has been identified as the most limiting process in term of calculation performances. It should probably be improved by considering the resolution scheme for this unit.

\section{Conclusion}

In this paper, an original approach for modeling water and pesticide transfer and fate in small agricultural landscapes has been proposed with some application cases comparing management scenarios of a hillslope. PESHMELBA makes it possible to take into account the diversity of landscape elements and to assess their influence on transfers by easily adding or removing new components, but also modifying the description of the processes. The landscape is described as a combination of linear and surface elements connected in surface and subsurface. Relevant processes for water circulation and pesticide fate are represented on each element individually with different levels of complexity. The coupling performed by the OpenPALM coupler is innovative and very efficient, giving high flexibility to handle spatially distributed modeling and complex time management, and to include distinct elements and processes with different conceptualizations. The scenarios tested in this paper showed that PESHMELBA is able to simulate water and solute fate in various configurations that are easily implemented. However, some elements still need to be included before reaching applications on real agricultural catchments, in particular grass buffer strips, hedges, artificial wetlands or drained plots. Future research should focus on the evaluation of PESHMELBA at the catchment scale. It should be performed by applying PESHMELBA on a real agricultural catchment with comprehensive experimental datasets such as the Kervidy catchment. Evaluation on real catchments with contrasted characteristics should also be targeted. Global sensitivity analysis methods is recommended to analyze the influence of input factors in such a modular tool, but also to evaluate the associated uncertainty (Fu et al. 2019). Finally, to reduce this uncertainty, data assimilation will make it possible to combine satellite or field observations with this physico-conceptual approach and to constrain the model to respect observations. Although many improvements may be developed, this study proves the feasibility and the facilities to add new elements and to build such a model. PESHMELBA is a new and promising tool that could be used in the next future for contamination risk management

or for local agricultural watershed management dedicated to improve surface water quality.

\section{Acknowledgement}

This research was supported by the French Agency for the Biodiversity.

\section{Appendix A. Nomenclature}

\begin{tabular}{lll}
\hline$a_{b l}$ & {$[-]$} & radiation interception by the vegetation coefficient \\
$c$ & {$\left[\mathrm{ML}^{-3}\right]$} & solute concentration in water \\
$c_{0}$ & {$\left[\mathrm{ML}^{-3}\right]$} & solute concentration in solution at time 0 \\
$\Delta h$ & {$[\mathrm{~L}]$} & head loss between groundwater and the river
\end{tabular}




\begin{tabular}{|c|c|c|}
\hline$\Delta_{i}$ & {$[\mathrm{~L}]$} & thickness of water table within the soil horizon i \\
\hline$\delta$ & {$[-]$} & fraction of wet vegetation \\
\hline$D$ & {$\left[\mathrm{~L}^{2} \mathrm{~T}^{-1}\right]$} & hydrodynamic dispersion coefficient \\
\hline DT50 & {$\left[\mathrm{T}^{-1}\right]$} & half-life \\
\hline$\eta$ & {$[-]$} & Brooks and Corey hydraulic conductivity shape parameter \\
\hline$E_{p}$ & {$\left[\mathrm{LT}^{-1}\right]$} & potential evaporation \\
\hline$E_{w}$ & {$\left[\mathrm{LT}^{-1}\right]$} & energy used to evaporate water from the interception tank \\
\hline$F_{1} 0$ & {$[-]$} & fraction of the root length density in the top $10 \%$ of the root zone \\
\hline$f_{o c}$ & $\%$ & soil organic carbon content \\
\hline$\gamma$ & {$[-]$} & anisotropy coefficient between horizontal and vertical hydraulic conductivity \\
\hline$H_{r}$ & {$[\mathrm{~L}]$} & river stage level \\
\hline$h$ & {$[\mathrm{~L}]$} & pressure head \\
\hline$h_{e}$ & {$[\mathrm{~L}]$} & capillary pressure (bubbling pressure) \\
\hline$h_{w}$ & {$[\mathrm{~L}]$} & water level on a plot \\
\hline$K_{h}$ & {$\left[\mathrm{LT}^{-1}\right]$} & vertical hydraulic conductivity \\
\hline$K_{d}$ & {$\left[\mathrm{~L}^{3} \mathrm{M}^{-1}\right]$} & linear coefficient of adsorption \\
\hline$K_{f}$ & {$\left[\left(\mathrm{~L}^{3}\right)^{n_{f}} \mathrm{M}^{1-n_{f}} \mathrm{M}^{-1}\right]$} & Freundlich coefficient of adsorption \\
\hline$K_{d o c}$ & {$\left[\mathrm{~L}^{3} \mathrm{M}^{-1}\right]$} & linear organic carbon-water partition coefficient \\
\hline$K_{f o c}$ & {$\left[\left(\mathrm{~L}^{3}\right)^{n_{f}} \mathrm{M}^{1-n_{f}} \mathrm{M}^{-1}\right]$} & non-linear organic carbon-water partition coefficient \\
\hline$K_{s, h}$ & {$\left[\mathrm{LT}^{-1}\right]$} & horizontal hydraulic conductivity at saturation \\
\hline$K_{s, v}$ & {$\left[\mathrm{LT}^{-1}\right]$} & vertical hydraulic conductivity at saturation \\
\hline$K_{s, h}^{i n t}$ & {$\left[\mathrm{LT}^{-1}\right]$} & horizontal hydraulic conductivity at saturation at the interface \\
\hline$\lambda$ & {$[-]$} & Brooks and Corey shape parameter (pore size index) \\
\hline$L A I$ & {$[-]$} & Leaf Area Index \\
\hline$L_{i}$ & {$[-]$} & length of interface with a given element $i$ connected downstream \\
\hline$n_{f}$ & {$[-]$} & exponent of Freundlich equation for adsorption equilibrium \\
\hline$n$ & {$\left[\mathrm{LT}^{1 / 3}\right]$} & Manning coefficient \\
\hline$P$ & {$\left[\mathrm{LT}^{-1}\right]$} & rain intensity above the canopy \\
\hline$P_{g}$ & {$\left[\mathrm{LT}^{-1}\right]$} & actual rainfall rate that reaches the soil surface \\
\hline$P E T$ & {$\left[\mathrm{LT}^{-1}\right]$} & potential evapotranspiration \\
\hline$q_{a d s}$ & {$\left[\mathrm{M} \mathrm{M}^{-1}\right]$} & mass of solute adsorbed per mass of soil at the equilibrium \\
\hline$q_{z}$ & {$\left[\mathrm{LT}^{-1}\right]$} & vertical pore velocity \\
\hline$\sigma_{f}$ & {$[-]$} & fraction of solar radiation and precipitation intercepted by the vegetation \\
\hline$S_{0}$ & {$\left[\mathrm{LL}^{-1}\right]$} & slope on the plot \\
\hline$s$ & {$[\mathrm{~L}]$} & length of seepage face \\
\hline$s_{i}$ & {$\left[\mathrm{LL}^{-1}\right]$} & $\begin{array}{l}\text { altitude gradient between the centroid of the plot and a given element } i \text { connected } \\
\text { downstream }\end{array}$ \\
\hline$\theta$ & {$\left[\mathrm{L}^{3} \mathrm{~L}^{-3}\right]$} & volumetric water content \\
\hline
\end{tabular}




\begin{tabular}{lll}
$\theta_{s}$ & {$\left[\mathrm{~L}^{3} \mathrm{~L}^{-3}\right]$} & volumetric water content at saturation \\
$T_{r}$ & {$\left[\mathrm{LT}^{-1}\right]$} & real transpiration \\
$T_{p}$ & {$\left[\mathrm{LT}^{-1}\right]$} & potential transpiration \\
$W_{b}$ & {$[\mathrm{~L}]$} & bottom width \\
$W_{t}$ & {$[\mathrm{~L}]$} & top width \\
$w_{i}$ & {$[-]$} & splitting weight for runoff toward a given element $i$ connected downstream \\
$w_{W T}^{i}$ & {$[-]$} & weight associated to numerical cell i within the water table WT for lateral saturated \\
& & transfer \\
$w_{r m a x}$ & {$[\mathrm{~L}]$} & maximal height of leaves interception tank \\
$w_{r o}$ & {$[\mathrm{~L}]$} & water height that overflows from the interception tank \\
$Z_{R}$ & {$[\mathrm{~L}]$} & rooting depth \\
$z_{i}$ & {$[\mathrm{~L}]$} & thickness of numerical cell i \\
\hline
\end{tabular}

\section{Appendix B. Details on PESHMELBA units}

445 Appendix B.1. FRER1D

The FRER1D (Fast 1D Richards Equation Resolution) model solves the vertical Richards' equation (Richards, 1931) (eq B.1 on homogeneous and heterogeneous soils, that is:

$$
\frac{\partial \theta}{\partial t}=\frac{\partial}{\partial z}\left[K_{v}(h)\left(\frac{\partial h}{\partial z}-1\right)\right]+R
$$

where $\theta$ is the volumetric water content $\left[\mathrm{L}^{3} \mathrm{~L}^{-3}\right], h$ the pressure head $[\mathrm{L}], K_{v}$ the vertical hydraulic conductivity $\left[\mathrm{LT}^{-1}\right]$ and $R$ a potential source/sink term $\left[\mathrm{L}^{3} \mathrm{~L}^{-3} \mathrm{~T}^{-1}\right]$. (Brooks \& Corey, 1964) (eq B.2 which allows an analytical formulation of the Kirchhoff transform proposed by Gardner (1958) and Campbell (1985) (eq B.3 for each soil horizon:

$$
\begin{aligned}
\frac{\theta}{\theta_{s}} & =\left(\frac{h}{h_{e}}\right)^{-\lambda} \\
\frac{K_{v}}{K_{s, v}} & =\left\{\begin{array}{cc}
\left(\frac{\theta}{\theta_{s}}\right)^{\eta}, & \text { si } h<h_{e} \\
1, & \text { si } h \geq h_{e}
\end{array}\right. \\
\phi & =\int_{-\infty}^{h} K_{v}(h) d h
\end{aligned}
$$

where $h_{e}$ is the air entry pressure [L], $K_{s, v}$ the vertical hydraulic conductivity at saturation $\left[\mathrm{LT}^{-1}\right]$, and $\lambda$ and $\eta$ the shape parameters of the Brooks and Corey model [-]. Regarding solute transport and transformation, the

original version of FRER1D solves the 1D advection-dispersion equation based on the same numerical scheme than for water transport:

$$
D \frac{\partial^{2} c}{\partial z^{2}}-q_{z} \frac{\partial c}{\partial z}+r=\frac{\partial c}{\partial t}
$$


where $D$ is the coefficient of hydrodynamic dispersion $\left[\mathrm{L}^{2} \mathrm{~T}^{-1}\right]$ (the contribution of diffusion to solute dispersion is ignored in this solution), $c$ the pesticide concentration in solution at the equilibrium $\left[\mathrm{ML}^{-3}\right], q_{z}$ the vertical pore velocity $\left[\mathrm{LT}^{-1}\right]$ and $r$ a potential source/sink term $\left[\mathrm{ML}^{-3} \mathrm{~T}^{-1}\right]$.

Potential evaporation and rain rate are converted into rain reaching the soil surface and plant transpiration in the PARTITION module as previously done by Varado et al. (2006a). First, the potential evapotranspiration PET $\left[\mathrm{LT}^{-1}\right]$ is split between potential evaporation and potential transpiration using a Beer-Lambert law and the LAI [-] (Leaf Area Index) (Huygen et al., 1997):

$$
\begin{aligned}
T_{p} & =P E T\left(1-\exp \left(-a_{b l} L A I\right)\right) \\
E_{p} & =P E T \exp \left(-a_{b l} L A I\right)
\end{aligned}
$$

where $a_{b l}[-]$ is a coefficient that accounts for interception of the radiation by the vegetation. $E_{p}$ is directly used in FRER1D as a surface boundary condition. Leaves constitute an interception tank which maximal height $w_{r \max }$ [L] is a function of the LAI (Noilhan \& Planton, 1989):

$$
w_{\text {rmax }}=2.10^{-4} \sigma_{f} L A I
$$

where $\sigma_{f}$ is the fraction of solar radiation and precipitation intercepted by the vegetation [-] (Taconet et al., 1986):

$$
\sigma_{f}=1-\exp \left(-a_{b l} L A I\right)
$$

The actual rainfall rate $P_{g}\left[\mathrm{LT}^{-1}\right]$ that reaches the soil surface is deduced by adding the rain that is not intercepted by the vegetation and the water that overflows from the interception tank:

$$
P_{g}=P * \exp \left(-a_{b l} L A I\right)+\frac{w_{r o}}{d t}
$$

where $P$ is the rain intensity above the canopy $\left[\mathrm{LT}^{-1}\right]$ and $w_{r_{o}}$ the water height that overflows from the interception $\operatorname{tank}[\mathrm{L}]$.

Finally, water root extraction is determined for each numerical cell of the soil column in the ROOT unit as done in $\mathrm{Li}$ et al. (2001). $R_{e x}$ is expressed as a linear function of the potential transpiration and three empirical coefficients:

$$
R_{e x}=\alpha \beta g T_{p}
$$

where $\alpha$ stands for the compensation mechanism, $\beta$ for water stress and $g$ for the root density. Such coefficients are function of the rooting depth $Z_{r}[\mathrm{~L}]$ and $F_{10}$ the fraction of the root length density in the top $10 \%$ of the root zone. They are extensively described in Li et al. (2001) and Braud et al. (2005).

\section{Appendix B.3. PPI}

Appendix B.3.1. Hydraulic conductivity calculation

$K_{s, h}^{i n t}$ is calculated as the harmonic mean between $K_{s, h}^{x}$ and $K_{s, h}^{y}$, the horizontal conductivities at saturation associated to the cells involved in the transfer for each column (Bouwer, 1969):

$$
\frac{d_{x}+d_{y}}{K_{s, h}^{i n t}}=\frac{d_{x}}{K_{s, h}^{x}}+\frac{d_{y}}{K_{s, h}^{y}}
$$


Where $d_{x}$ and $d_{y}$ are the distances from the centroids of the columns to the interface [L]. For a given column $C_{0} l_{x}$, if a water table extends on $\mathrm{M}$ soil horizons, the associated horizontal hydraulic conductivity $K_{s, h}^{x}$ is expressed as :

$$
K_{s, h}^{x}=\frac{\sum_{i=1}^{M} \Delta^{i} K_{s, h}^{i}}{\sum_{i=1}^{M} \Delta^{i}}
$$

Where $\Delta_{i}$ is the thickness of the water table within the soil horizon $i[\mathrm{~L}]$ and $K_{s, h}^{i}$ the horizontal hydraulic conductivity at saturation associated to the soil horizon $i\left[\mathrm{LT}^{-1}\right]$. Various authors have reported anisotropy of hydraulic conductivity with higher conductivity in the horizontal direction than in the vertical direction (Kanwar taken into account with an anisotropy coefficient $\gamma\left(\gamma=K_{s, h} / K_{s, v}\right)$.

Appendix B.3.2. Coefficients for flow splitting

For a given water table $W T$ spread on $\mathrm{N}$ numerical cells, the weight $w_{W T}^{i}$ for cell $i, i \in\{1, \ldots, N\}$ is :

$$
w_{W T}^{i}=\frac{\frac{z^{i}}{K_{s, h}^{i}}}{\sum_{j=1}^{N} \frac{z^{j}}{K_{s, h}^{j}}}
$$

where $z^{i}$ is the thickness of the numerical cell $i[\mathrm{~L}]$ and $K_{s, h}^{i}$ its horizontal hydraulic conductivity at saturation $\left[\mathrm{LT}^{-1}\right]$. Upstream, those coefficients are equal to 0 for non saturated cells.

\section{Appendix C. Parameters for vegetation used in application tests}

\begin{tabular}{ccc}
\hline Crop coefficient & - & 1.0 \\
\hline Extinction coefficient & - & 0.5 \\
\hline $\begin{array}{c}\text { Pressure heads that determine the } \alpha \text { sink term in } \mathrm{Li} \\
\text { et al. (2001) root extraction formulation } \mathrm{h} 1, \mathrm{~h} 2, \\
\mathrm{~h} 3 \mathrm{a}, \mathrm{h} 3 \mathrm{~b}, \mathrm{~h} 4\end{array}$ & $\mathrm{~m}$ & $-0.1 /-0.25 /-5.0 /-10.0 /-150.0$ \\
\hline LAI & $\mathrm{m} / \mathrm{s}$ & $1.16 \quad 10^{-6} / 5.7910^{-6}$ \\
\hline Associated potential transpiration e1, e2 & - & $\begin{array}{c}\text { Increases linearly between } 2.2 \text { at } \mathrm{t}=0 \mathrm{~h} \text { and } 4 \\
\text { at } \mathrm{h}=240 \mathrm{~h}\end{array}$ \\
\hline F10 & $\mathrm{m}$ & $\begin{array}{c}\text { Increases linearly between } 0.15 \text { at } \mathrm{t}=0 \mathrm{~h} \text { and } \\
0.471 \mathrm{at} \mathrm{h}=240 \mathrm{~h}\end{array}$ \\
\hline & - & $\begin{array}{c}\text { Increases linearly between } 0 \text { at } \mathrm{t}=0 \mathrm{~h} \text { and } 0.29 \\
\text { at } \mathrm{h}=240 \mathrm{~h}\end{array}$ \\
\hline
\end{tabular}




\section{References}

Abbott, M., Bathurst, J., Cunge, J., O'Connell, P., \& Rasmussen, J. (1986). An introduction to the european hydrological system — systeme hydrologique europeen, "she", 2: Structure of a physically-based, distributed modelling system. Journal of Hydrology, 87, 61-77. URL: http://www.sciencedirect.com/science/article/ pii/0022169486901150, doi 10.1016/0022-1694(86)90115-0.

Adriaanse, P. (1997). Exposure assessment of pesticides in field ditches: The TOXSWA model. Pesticide Science, 49, 210-212. doi 10.1002/(SICI) 1096-9063(199702) 49:2<210::AID-PS496>3.0.C0;2-1.

Adriaanse, P., Boesten, J., \& Crum, S. (2013). Estimating degradation rates in outdoor stagnant water by inverse ps.3435.

Alix, A., Brown, C., Capri, E., Goerlitz, G., Golla, B., Knauer, K., Laabs, V., Mackay, N., Vasile, A., Alonso Prados, E., Reinert, W., Streloke, M., \& Poulsen, V. (2017). Mitigating the Risks of Plant Protection Products in the Environment: MAgPIE. SETAC.

Argent, R., Perraud, J.-M., Rahman, J., Grayson, R., \& Podger, G. (2009). A new approach to water quality modelling and environmental decision support systems. Environmental Modelling E Software, 24,809 - 818. URL: http://www.sciencedirect.com/science/article/pii/S1364815208002351. doi:10.1016/j.envsoft. 2008.12.010.

Arnold, J., Srinivasan, R., Muttiah, R., \& Williams, J. (1998). Large area hydrologic modeling and assessment -

Part 1: Model development. Journal of the American Water Resources Association, 34, 73-89. doi:10.1111/j. 1752-1688.1998.tb05961.x.

Ashby, S., \& Falgout, R. (1996). A parallel multigrid preconditioned conjugate gradient algorithm for groundwater flow simulations. Nuclear Science and Engineering, 124, 145-159. doi:10.13182/NSE96-A24230.

Barthélémy, S., Ricci, S., Morel, T., Goutal, N., Pape, E. L., \& Zaoui, F. (2018). On operational flood forecasting system involving 1D/2D coupled hydraulic model and data assimilation. Journal of Hydrology, 562, 623 - 634. doi: $10.1016 / j \cdot j h y d r o l .2018 .05 .007$.

Beckers, J., \& Frind, E. (2000). Simulating groundwater flow and runoff for the oro moraine aquifer system. 口 part i. model formulation and conceptual analysis. Journal of Hydrology, 229, 265 - 280. URL: http://www. sciencedirect.com/science/article/pii/S0022169400001670, doi:10.1016/S0022-1694(00)00167-0.

Beisman, J. J., Maxwell, R. M., Navarre-Sitchler, A. K., Steefel, C. I., \& Molins, S. (2015). Parcrunchflow: an efficient, parallel reactive transport simulation tool for physically and chemically heterogeneous saturated subsurface environments. Computational Geosciences, 19, 403-422. URL: https://doi.org/10.1007/s10596-015-9475-x. doi $10.1007 / \mathrm{s} 10596-015-9475-\mathrm{x}$.

Beltman, W., \& Adriaanse, P. (1999). User's manual TOXSWA 1.2; Simulation of pesticides fate in small surface 
Beven, K. (1979). On the generalized kinematic routing method. Water Resources Research, 15, 1238-1242. doi:10.1029/WR015i005p01238.

Beven, K., \& Germann, P. (1982). Macropores and water flow in soils. Water Resources Research, 18, 1311-1325. doi $10.1029 /$ WR018i005p01311.

\section{1-3092. doi:10.1002/wrcr.20156.}

Bingner, T. F. Y. Y., R.L. (2011). AnnAGNPS technical processes documentation, Version 5.2. Technical Report United States Department of Agriculture.

Bouwer, H. (1969). Planning and interpreting soil permeability measurements. Journal of the Irrigation and

\section{Drainage Division, 95, 391-402.}

Branger, F., Braud, I., Debionne, S., Viallet, P., Dehotin, J., Henine, H., Nedelec, Y., \& Anquetin, S. (2010). Towards multi-scale integrated hydrological models using the LIQUIDß framework. overview of the concepts and first application examples. Environmental Modelling and Software, 25, 1672-1681. doi $10.1016 /$ j.envsoft. 2010.06 .005 .

Branger, F., Tournebize, J., Carluer, N., Kao, C., Braud, I., \& Vauclin, M. (2009). A simplified modelling approach for pesticide transport in a tile-drained field: The PESTDRAIN model. Agricultural Water Management, 96, 415-428. doi $10.1016 /$ j.agwat.2008.09.005.

Braud, I., Varado, N., \& Olioso, A. (2005). Comparison of root water uptake modules using either the surface energy balance or potential transpiration. Journal of Hydrology, 301, 267 - 286. doi 10.1016/j.jhydrol.2004.06.033.

Brooks, R. H., \& Corey, A. T. (1964). Hydraulic Properties of Porous Media. Technical Report 1 Colorado Stae University, Fort Colins.

Buchanan, B. P., Falbo, K., Schneider, R. L., Walter, M. T., \& Easton, Z. M. (2013). Hydrological impact of roadside ditches in an agricultural watershed in Central New York: implications for non-point source pollutant transport. Hydrological Processes, 27, 2422-2437. doi 10.1002/hyp.9305.

Buis, S., Piacentini, A., \& Déclat, D. (2006). PALM: a computational framework for assembling high-performance computing applications. Concurrency and Computation: Practice and Experience, 18, 231-245. doi:10.1002/ cpe.914.

Buytaert, W., Reusser, D., Krause, S., \& J.-P., R. (2008). Why can't we do better than Topmodel? Hydrological Processes, 22, 4175-4179. doi 10.1002/hyp.7125. arXiv:https://onlinelibrary.wiley.com/doi/pdf/10.1002/hyp.7125.

Campbell, G. (1985). Soil Physics With Basic Transport Models for Soil-Plant Systems volume 14. Elsevier.

Campbell, N., D’Arcy, B., Frost, A., Novotny, V., \& Sampson, A. (2004). Diffuse Pollution: An Introduction to the Problems and Solutions. IWA Publishing. 
Camporese, M., Paniconi, C., Putti, M., \& Orlandini, M. (2010). Surface-subsurface flow modeling with path-based runoff routing, boundary condition-based coupling, and assimilation of multisource observation data. Water Resources Research, 46. doi:10.1029/2008WR007536.

Carluer, N., Catalogne, C., Dages, C., \& Tournebize, J. (2017a). Aménager le territoire et gérer les aménagements : les zones tampons sèches et humides, les fossés pour lutter contre les pollutions diffuses par les produits phytosanitaires dans les aires de captage. Innovations Agronomiques, 57, 117-139.

Carluer, N., Lauvernet, C., Noll, D., \& Muñoz-Carpena, R. (2017b). Defining context-specific scenarios to design vegetated buffer zones that limit pesticide transfer via surface runoff. Science of The Total Environment, 575, 701 - 712. doi $10.1016 /$ j.scitotenv.2016.09.105.

Carluer, N., \& Marsily, G. D. (2004). Assessment and modelling of the influence of man-made networks on the hydrology of a small watershed: implications for fast flow components, water quality and landscape management. Journal of Hydrology, 285, 76 - 95. doi $10.1016 / j \cdot j$ hydrol.2003.08.008

Carsel, J., E., \& Baldwin, J. E. (2000). PRZM-3, A model for predicting Pesticide and nitrogen fate in the crop root and unsaturated soil zones. Technical Report Environmental Protection Agency.

Cash, R. J., \& Karp, A. (1990). A variable order RungeKutta method for value problems with rapidly varying right-hand sides. ACM Transactions on Mathematical Software, 16, 201-222. doi 10.1145/79505.79507.

Cheverry, C. (1998). Agriculture intensive et qualité des eaux. Editions Quae.

Chiew, F., McMahon, T., \& O'Neill, I. (1992). Estimating groundwater recharge using an integrated surface and q groundwater modelling approach. Journal of Hydrology, 131, 151 - 186. URL: http://www.sciencedirect. com/science/article/pii/002216949290216I, doi 10.1016/0022-1694(92)90216-I.

Crevoisier, D., Chanzy, A., \& Voltz, M. (2009). Evaluation of the Ross fast solution of Richards' equation in 570 u unfavourable conditions for standard finite element methods. Advances in Water Resources, 32, 936-947. doi 10. 1016/j.advwatres.2009.03.008.

Dauptain, A., Favier, J., \& Bottaro, A. (2008). Hydrodynamics of ciliary propulsion. Journal of Fluids and Structures, 24, 1156 - 1165. doi:10.1016/j.jfluidstructs.2008.06.007

De Roo, A., Wesseling, C., Jetten, V., \& Ritsema, C. (1996). LISEM: A physically-based hydrological and soil erosion model incorporated in a GIS. In In: K. Kovar \&3 H.P. Nachtnebel (eds.), Application of geographic information systems in hydrology and water resources management. Wallingford (UK), IAHS, 1996. IAHS Publ. 235, pp. 395-403 (pp. $395-403$ ).

Dehotin, J. (2007). Prise en compte de l'hétérogénéité des surfaces continentales dans la modélisation hydrologique spatialisée. Application sur le haut-bassin de la Saône.. Ph.D. thesis Institut National Polytechnique de Grenoble France, Europe. 
Djabelkhir, K. (2015). Computer modeling of pesticide fate at hillslope scale within a hydrological modeling framework taking into account macroporosity (in French). Ph.D. thesis Université Grenoble Alpes.

Djabelkhir, K., Lauvernet, C., Kraft, P., \& Carluer, N. (2017). Development of a dual permeability model within a hydrological catchment modeling framework: 1d application. Science of The Total Environment, 575, $1429-$

Dollinger, J. (2016). Analyse et modélisation des transferts et de la rétention de pesticides dans les fossés agricoles infiltrants en lien avec les stratégies d'entretien. Ph.D. thesis Laboratoire d'étude des Interactions Sol Agrosystème - Hydrosystème (LISAH).

Dollinger, J., Dagès, C., Negro, S., Bailly, J.-S., \& Voltz, M. (2016). Variability of glyphosate and diuron sorption capacities of ditch beds determined using new indicator-based methods. Science of The Total Environment, 573, 716 - 726. doi $10.1016 /$ j.scitotenv. 2016.08.168

Dosskey, M. G., Helmers, M. J., \& Eisenhauer, D. E. (2006). An approach for using soil surveys to guide the placement of water quality buffers. Journal of Soil and Water Conservation, 61, 344-354. doi:61(6):344-354.

Dubus, I., \& Surdyk, N. (2006). State-of-the-art review on pesticide fate models and environmental indicators.

URL: http://www.eu-footprint.org/downloads/FOOTPRINT_DL4.pdf.

Duchaine, F., Jauré, S., Poitou, D., Quémerais, E., Staffelbach, G., Morel, T., \& L.Y.M., G. (2015). Analysis of high performance conjugate heat transfer with the openpalm coupler. Computational Science 6 Discovery, 8. doi $10.1088 / 1749-4699 / 8 / 1 / 015003$.

Elsaesser, D., Stang, C., Bakanov, N., \& Schulz, R. (2013). The Landau stream mesocosm facility: Pesticide mitigation in vegetated flow-through streams. Bulletin of Environmental Contamination and Toxicology, 90, 640-645. doi:10.1007/s00128-013-0968-9.

Fabre, J.-C., Louchart, X., Colin, F., Dagès, C., Moussa, R., Rabotin, M., Raclot, D., Lagacherie, P., \& Voltz, M. (2010). OpenFLUID : a software environment for modelling fluxes in landscapes. In LandMod 2010: International Conference on Integrative Landscape Modelling . 2010; International Conference on Integrative Landscape Modelling, Montpellier, FRA, 2010-02-03-2010-02-05, 1-13 (pp.-).

Fatichi, S., Vivoni, E., Ogden, F., Ivanov, V., Mirus, B., Gochis, D., Downer, C., Camporese, M., Davison, J., Ebel, B., Jones, N., Kim, J., Mascaro, G., Niswonger, R., Restrepo, P., Rigon, R., Shen, C., Sulis, M., \& Tarboton, D. (2016). An overview of current applications, challenges, and future trends in distributed process-based models in hydrology. Journal of Hydrology, 537, 45-60. doi:10.1016/j.jhydrol.2016.03.026

Flury, M., Leuenberger, J., Studer, B., \& Flühler, H. (1995). Transport of anions and herbicides in a loamy and a sandy field soil. Water Resources Research, 31, 823-836. doi 10.1029/94WR02852.

Focus (2007). Landscape and mitigation factors in aquatic risk assessment. Volume 2: detailed technic. Technical Report European Commission. 
Fouilloux, A., \& Piacentini, A. (1999). The PALM project: MPMD paradigm for an oceanic data assimilation software. In Euro-Par'99 Parallel Processing: 5th International Euro-Par Conference Toulouse, France, August 31 - September 3, 1999 Proceedings (pp. 1423-1430). Berlin, Heidelberg: Springer Berlin Heidelberg.

Fu, B., Merritt, W. S., Croke, B. F., Weber, T. R., \& Jakeman, A. J. (2019). A review of catchment-scale water quality and erosion models and a synthesis of future prospects. Environmental Modelling ES Software, 114, 75 - 97. URL: http://www.sciencedirect.com/science/article/pii/S1364815218307461. doi 10.1016/j.envsoft.

Gaillardon, P., \& Sabar, M. (2006). Changes in the concentration of isoproturon und its degradation products in 口 soil und soil solution during incubation at two different temperatures. Weed Research, 34, $243-250$. doi 10. $1111 / j \cdot 1365-3180.1994 . t b 01992 \cdot x$.

Gardner, W., R (1958). Some steady-state solutions of the unsaturated moisture flow equation with application to evaporation from a water table. Soil Science, 85, 228-232. doi 10.1097/00010694-195804000-00006.

Gassmann, M., Stamm, C., Olsson, O., Lange, J., Kümmerer, K., \& Weiler, M. (2013). Model-based estimation of pesticides and transformation products and their export pathways in a headwater catchment. Hydrology and Earth System Sciences, 17, 5213-5228. doi 10.5194/hess-17-5213-2013.

Gatel, L., Lauvernet, C., Carluer, N., Weill, S., Tournebize, J., \& Paniconi, C. (2018). Global evaluation and sensitivity analysis of a physically based flow and reactive transport model on a laboratory experiment. Environmental Modelling and Software, .

Gevaert, V., Van Griensven, A., Holovet, K., Seunjtjens, J., \& P.A., V. (2008). SWAT developments and recommendations for modelling agricultural pesticide mitigation measures in river basins. Hydrological Sciences Journal, 53, 1075-1089. doi 10.1623/hysj.53.5.1075, arXiv:https://doi.org/10.1623/hysj.53.5.1075. art review. Technical Report HR Wallingford.

Huygen, J., Van Dam, J., Kroes, J., \& Wesseling, J. (1997). SWAP 2.0: input and output manual. Wageningen Agricultural University.

Ippolito, A., \& Fait, G. (2019). Pesticides in surface waters: from edge-of-field to global modelling. Current Opinion S1877343518300290, doi doi.org/10.1016/j.cosust.2018.10.023. Environmental Change Assessment.

Jarvis, N. (2007). A review of non-equilibrium water flow and solute transport in soil macropores: Principles, 口 controlling factors and consequences for water quality. European Journal of Soil Science, 58, 523-546. doi 10. $1111 / \mathrm{j} .1365-2389.2007 .00915 \cdot \mathrm{x}$. saturated flow problems. Advances in Water Resources, 24, 763-774. doi 10.1016/S0309-1708(00)00075-0. 
Jones, J. A., Swanson, F. J., Wemple, B. C., \& Snyder, K. U. (2000). Effects of roads on hydrology, geomorphology, $\square$ and disturbance patches in stream networks. Conservation Biology, 14, 76-85. URL: https://onlinelibrary. wiley.com/doi/abs/10.1046/j.1523-1739.2000.99083.x. doi:10.1046/j.1523-1739.2000.99083.x.

Kanwar, R., A. Rizvi, H., Ahmed, M., \& Horton, R. (1990). Measurement of field-saturated hydraulic conductivity

\ by using guelph and velocity permeameters. American Society of Agricultural Engineers, 32. doi:10.13031/ 2013.31239 .

Kneis, D. (2015). A lightweight framework for rapid development of object-based hydrological model engines.

Environmental Modelling \& Software, 68, 110 -121. URL: http://www.sciencedirect.com/science/article/ pii/S1364815215000584 doi $10.1016 / j$.envsoft.2015.02.009.

Kollet, S., \& Maxwell, R. (2006). Integrated surface-groundwater flow modeling: A free-surface overland flow 1016/j.advwatres.2005.08.006. Cited By 321.

660

Kraft, P., Vache, K. B., Frede, H.-G., \& Breuer, L. (2012). CMF: A hydrological programming language extension

口 for integrated catchment models. Environmental Modelling and Software, 26, 828-830. doi 10.1016/j.envsoft. 2010.12.009.

Kralisch, S., \& Krause, P. (2006). Jams - a framework for natural resource model development and application. In Proceedings of the iEMSs 3rd Biennial Meeting," Summit on Environmental Modelling and Software. URL: https://www.scopus. com/inward/record.uri?eid=2-s2.0-84858643466\&partnerID=40\&md5= cb2f0342fb5b341a9046a98e22bcae0b cited By 33.

Krone-Davis, P., Watson, F., Huertos, M. L., \& Starner, K. (2013). Assessing pesticide reduction in constructed wetlands using a tanks-in-series model within a bayesian framework. Ecological Engineering, 57, $342-352$. doi $10.1016 /$ j.ecoleng. 2013.04.053.

Lacas, J.-G., Voltz, M., Gouy, V., Carluer, N., \& Gril, J.-J. (2005). Using grassed strips to limit pesticide transfer to surface water: A review. Sustainable Agriculture, (pp. 471-491). doi:10.1007/978-90-481-2666-8_30.

Lammoglia, S.-K., Moeys, J., Barriuso, E., Larsbo, M., Marín-Benito, J.-M., Justes, E., Alletto, L., Ubertosi, M., Nicolardot, B., Munier-Jolain, N., \& Mamy, L. (2017). Sequential use of the STICS crop model and of the MACRO pesticide fate model to simulate pesticides leaching in cropping systems. Environmental Science and Pollution Research, 24, 6895-6909. doi:10.1007/s11356-016-6842-7.

Larsbo, M., \& Jarvis, N. (2003). MACRO 5.0: A Model of Water Flow and Solute Transport in Macroporous Soil : Technical Description. Emergo (Uppsala). Department of Soil Sciences, Swedish University of Agricultural Sciences. 
Lauvernet, C., Helbert, C., Catalogne, C., Carluer, N., \& Muñoz-Carpena, R. (2016). Sensitivity analysis and metamodeling methods for designing buffer strips to protect water from pesticide transfers. In International conference on sensitivity analysis of model output, 30/11/2016-03/12/2016, La Réunion, FRA / Sensitivity Analysis of Model Output (SAMO) PROCEEDINGS (pp. 58-60). Le Tampon: University of Reunion Island.

Lauvernet, C., \& Muñoz-Carpena, R. (2018). Shallow water table effects on water, sediment, and pesticide transport in vegetative filter strips - Part 2: model coupling, application, factor importance, and uncertainty. Hydrology and Earth System Sciences, 22, 71-87. doi 10.5194/hess-22-71-2018.

Leopold, L. B., \& Dunne, T. (1978). Water in environmental planning. Freeman, W. H.

Lewis, K. A., Tzilivakis, J., Warner, D. J., \& Green, A. (2016). An international database for pesticide risk assessments and management. Human and Ecological Risk Assessment: An International Journal, 22, 1050-1064. URL: https://doi.org/10.1080/10807039.2015.1133242, doi 10.1080/10807039.2015.1133242.

Li, K., De Jong, R., \& Boisvert, J. (2001). An exponential root-water-uptake model with water stress compensation. Journal of Hydrology, 252, 189-204. doi 10.1016/S0022-1694(01)00456-5.

Li, R.-M., B. Simons, D., \& A. Stevens, M. (1975). Nonlinear kinematic wave approximation for water routing. Water Resources Research, 11, 245-252. doi:10.1029/WR011i002p00245.

Margoum, C., Gouy, V., Williams, R., \& Smith, J. (2001). Le rôle des fossés agricoles dans la dissipation des produits phytosanitaires. Ingénieries - EAT, 1, 55-65. doi:10.7202/705514ar.

Miles, J. (1985). The representation of flows to partially penetrating rivers using groundwater flow models. Journal of Hydrology, 82, 341-355. doi 10.1016/0022-1694(85)90026-5.

Moussa, R., \& Bocquillon, C. (1996). Criteria for the choice of flood-routing methods in natural channels. Journal of Hydrology, 186, 1-30. doi 10.1016/S0022-1694(96)03045-4.

Muñoz-Carpena, R., Lauvernet, C., \& Carluer, N. (2018). Shallow water table effects on water, sediment, and pesticide transport in vegetative filter strips - Part 1: nonuniform infiltration and soil water redistribution. Hydrology and Earth System Sciences, 22, 53-70. doi:10.5194/hess-22-53-2018.

Muñoz-Carpena, R., Parsons, J. E., \& Gilliam, J. (1999). Modeling hydrology and sediment transport in vegetative filter strips. Journal of Hydrology, 214, 111-129. doi 10.1016/S0022-1694(98)00272-8.

Noilhan, J., \& Planton, S. (1989). A simple parameterization of land surface processes for meteorological models. Monthly Weather Review, 117, 536-549. doi 10.1175/1520-0493(1989)117<0536:ASPOLS>2.0.C0;2.

Paniconi, C., \& Putti, M. (1994). A comparison of Picard and Newton iteration in the numerical solution of multidimensional variably saturated flow problems. Water Resources Research, 30, 710 3357-3374-. URL: http://search.ebscohost.com/login. aspx?direct=true\&db=edselc\&AN=edselc.2-52. 0-0028666563\&lang=fr\&site=eds-live, doi:10.1029/94WR02046. 
Poletika, N., Coody, P., Fox, G., J Sabbagh, G., C Dolder, S., \& White, J. (2009). Chlorpyrifos and atrazine removal from runoff by vegetated filter strips: Experiments and predictive modeling. Journal of Environmental Quality, $38,1042-52$. doi $10.2134 /$ jeq2008.0404.

Reichenberger, S., Bach, M., Skitschak, A., \& Frede, H.-G. (2007). Mitigation strategies to reduce pesticide inputs into ground- and surface water and their effectiveness; a review. Science of The Total Environment, 384, 1-35. doi $10.1016 / \mathrm{j}$.scitotenv. 2007.04 .046 .

Richards, L., A (1931). Capillary conduction of liquids in porous mediums. Physics, 1, 318 - 333. doi 10.1063/1. 1745010 .

720 Ross, P. (2003). Modeling soil water and solute transport - fast, simplified numerical solutions. Agronomy Journal, 95, 1352-1361. doi 10.2134/agronj2003.1352.

Sabbagh, G., Fox, G., Kamanzi, A., Roepke, B., \& Tang, J.-Z. (2009). Effectiveness of vegetative filter strips in reducing pesticide loading: Quantifying pesticide trapping efficiency. Journal of Environmental Quality, 38, 762-71. doi:10.2134/jeq2008.0266

Simpkins, W., Wineland, T., Andress, R., Johnston, D., Caron, G., Isenhart, T., \& Schultz, R. (2002). Hydrogeological constraints on riparian buffers for reduction of diffuse pollution: examples from the Bear Creek watershed in Iowa, USA. Water Science and Tech., 45, 61-68. URL: http://www.iwaponline.com/wst/04509/ wst045090061.htm.

Stehle, S., Elsaesser, D., Gregoire, C., Imfeld, G., Niehaus, E., Passeport, E., Payraudeau, S., Schäfer, R. B., Tournebize, J., \& Schulz, R. (2011). Pesticide risk mitigation by vegetated treatment systems: A meta-analysis. Journal of Environmental Quality, 40, 1068-80. doi $10.2134 /$ jeq2010.0510.

Taconet, O., Bernard, R., \& Vidal-Madjar, D. (1986). Evapotranspiration over an agricultural region using a surface flux/temperature model based on NOAA-AVHRR data. Journal of Applied Meteorology, 25, 284-307. doi $10.1175 / 1520-0450(1986) 025<0284$ : EOAARU $>2.0$. CO;2 Methods to prioritize placement of riparian buffers for improved water quality. Agroforestry Systems, 75, 17-25. doi $10.1007 / \mathrm{s} 10457-008-9134-5$.

Varado, N., Braud, I., \& Ross, P. (2006a). Development and assessment of an efficient vadose zone module solving the 1d Richards' equation and including root extraction by plants. Journal of Hydrology, 323, 258-275. doi 10. $1016 / j \cdot j h y d r o l .2005 .09 .015$

Varado, N., Braud, I., Ross, P., \& Haverkamp, R. (2006b). Assessment of an efficient numerical solution of the 1d Richards' equation on bare soil. Journal of Hydrology, 323, 244 - 257. doi 10.1016/j.jhydrol.2005.07.052.

Villa-Vialaneix, N., Follador, M., Ratto, M., \& Leip, A. (2012). A comparison of eight metamodeling techniques for the simulation of N 2o fluxes and N leaching from corn crops. Environmental Modelling and Software, 34 , 
Warren, N., Allan, I., Carter, J., House, W., \& Parker, A. (2003). Pesticides and other microorganic contaminants in freshwater sedimentary environments - a review. Applied Geochemistry, 18, 159

q - 194. URL: http://www.sciencedirect.com/science/article/pii/S0883292702001592, doi https://doi. org/10.1016/S0883-2927(02)00159-2.

750 Weill, S., Mazzia, A., Putti, M., \& Paniconi, C. (2011). Coupling water flow and solute transport into a physically-

口 based surface-subsurface hydrological model. Advances in Water Resources, 34, 128 - 136. doi 10.1016/j. advwatres.2010.10.001.

Zhang, H. (1996). Anisotropic variation of saturated hydraulic conductivity of a variously grazed salt marsh soil. Journal of Plant Nutrition and Soil Science, 159, 129-135. doi 10.1016/j.still.2008.05.004 